\title{
Review Article \\ Biosynthesis of Nanoparticles by Microorganisms and Their Applications
}

\author{
Xiangqian Li, ${ }^{1,2}$ Huizhong $\mathrm{Xu},{ }^{3}$ Zhe-Sheng Chen, ${ }^{2}$ and Guofang $\mathrm{Chen}^{4}$ \\ ${ }^{1}$ School of Life Science and Chemical Engineering, Huaiyin Institute of Technology, Huai'an, Jiangsu 223003, China \\ ${ }^{2}$ Department of Pharmaceutical Sciences, College of Pharmacy and Allied Health Professions, Queens, NY 11439, USA \\ ${ }^{3}$ Department of Physics, St. John's College of Liberal Arts and Science, St. John's University, Queens, NY 11439, USA \\ ${ }^{4}$ Department of Chemistry, St. John's College of Liberal Arts and Science, St. John's University, Queens, NY 11439, USA
}

Correspondence should be addressed to Xiangqian Li, lixq2002@126.com and Guofang Chen, cheng@stjohns.edu

Received 16 May 2011; Accepted 31 May 2011

Academic Editor: Xing J. Liang

Copyright ( 12011 Xiangqian Li et al. This is an open access article distributed under the Creative Commons Attribution License, which permits unrestricted use, distribution, and reproduction in any medium, provided the original work is properly cited.

The development of eco-friendly technologies in material synthesis is of considerable importance to expand their biological applications. Nowadays, a variety of inorganic nanoparticles with well-defined chemical composition, size, and morphology have been synthesized by using different microorganisms, and their applications in many cutting-edge technological areas have been explored. This paper highlights the recent developments of the biosynthesis of inorganic nanoparticles including metallic nanoparticles, oxide nanoparticles, sulfide nanoparticles, and other typical nanoparticles. Different formation mechanisms of these nanoparticles will be discussed as well. The conditions to control the size/shape and stability of particles are summarized. The applications of these biosynthesized nanoparticles in a wide spectrum of potential areas are presented including targeted drug delivery, cancer treatment, gene therapy and DNA analysis, antibacterial agents, biosensors, enhancing reaction rates, separation science, and magnetic resonance imaging (MRI). The current limitations and future prospects for the synthesis of inorganic nanoparticles by microorganisms are discussed.

\section{Introduction}

Nanoparticles-particles having one or more dimensions of the order of $100 \mathrm{~nm}$ or less—have attracted great attention due to their unusual and fascinating properties, and applications advantageous over their bulk counterparts $[1,2]$. There are a large number of physical, chemical, biological, and hybrid methods available to synthesize different types of nanoparticles [3-6]. Although physical and chemical methods are more popular in the synthesis of nanoparticles, the use of toxic chemicals greatly limits their biomedical applications, in particular in clinical fields. Therefore, development of reliable, nontoxic, and eco-friendly methods for synthesis of nanoparticles is of utmost importance to expand their biomedical applications. One of the options to achieve this goal is to use microorganisms to synthesize nanoparticles.

Nanoparticles produced by a biogenic enzymatic process are far superior, in several ways, to those particles produced by chemical methods. Despite that the latter methods are able to produce large quantities of nanoparticles with a defined size and shape in a relatively short time, they are complicated, outdated, costly, and inefficient and produce hazardous toxic wastes that are harmful, not only to the environment but also to human health. With an enzymatic process, the use of expensive chemicals is eliminated, and the more acceptable "green" route is not as energy intensive as the chemical method and is also environment friendly. The "biogenic" approach is further supported by the fact that the majority of the bacteria inhabit ambient conditions of varying temperature, $\mathrm{pH}$, and pressure. The particles generated by these processes have higher catalytic reactivity, greater specific surface area, and an improved contact between the enzyme and metal salt in question due to the bacterial carrier matrix $[7,8]$.

Nanoparticles are biosynthesized when the microorganisms grab target ions from their environment and then turn the metal ions into the element metal through enzymes 
generated by the cell activities. It can be classified into intracellular and extracellular synthesis according to the location where nanoparticles are formed $[8,9]$. The intracellular method consists of transporting ions into the microbial cell to form nanoparticles in the presence of enzymes. The extracellular synthesis of nanoparticles involves trapping the metal ions on the surface of the cells and reducing ions in the presence of enzymes [10]. The biosynthesized nanoparticles have been used in a variety of applications including drug carriers for targeted delivery, cancer treatment, gene therapy and DNA analysis, antibacterial agents, biosensors, enhancing reaction rates, separation science, and magnetic resonance imaging (MRI).

This paper provides a brief overview of the current research activities that center on the biological synthesis of metallic nanoparticles, oxide nanoparticles, sulfide nanoparticles, and other types of nanoparticles. This is followed by discussions of the particle biosynthesis mechanisms and the conditions to control the size/shape and monodispersity of particles. Next, current applications of biosynthesized nanoparticles in the nanomedicine and biological fields are presented. The paper concludes with discussions on the current limitations and prospects of nanoparticle synthesis by microorganisms.

\section{Biological Synthesis of Nanoparticles by Microorganisms}

Biological entities and inorganic materials have been in constant touch with each other ever since inception of life on the earth. Due to this regular interaction, life could sustain on this planet with a well-organized deposit of minerals. Recently scientists become more and more interested in the interaction between inorganic molecules and biological species. Studies have found that many microorganisms can produce inorganic nanoparticles through either intracellular or extracellular routes. This section describes the production of various nanoparticles via biological methods following the categories of metallic nanoparticles including gold, silver, alloy and other metal nanoparticles, oxide nanoparticles consisting of magnetic and nonmagnetic oxide nanoparticles, sulfide nanoparticles, and other miscellaneous nanoparticles.

2.1. Metallic Nanoparticles. Some typical metal nanoparticles produced by microorganisms are summarized in Table 1 .

2.1.1. Gold Nanoparticles. Gold nanoparticles (AuNPs) have a rich history in chemistry, dating back to ancient Roman times where they were used to stain glasses for decorative purposes. AuNPs were already used for curing various diseases centuries ago. The modern era of AuNPs synthesis began over 150 years ago with the work of Michael Faraday, who was possibly the first to observe that colloidal gold solutions have properties that differ from bulk gold [11]. Biosynthesis of nanoparticles as an emerging bionanotechnology (the intersection of nanotechnology and biotechnology) has received considerable attention due to a growing need to develop environment-friendly technologies in materials synthesis. Sastry and coworkers have reported the extracellular synthesis of gold nanoparticles by fungus Fusarium oxysporum and actinomycete Thermomonospora sp., respectively $[12,13]$. They reported the intracellular synthesis of gold nanoparticles by fungus Verticillium sp. as well [14]. Southam and Beveridge have demonstrated that gold particles of nanoscale dimensions may readily be precipitated within bacterial cells by incubation of the cells with $\mathrm{Au}^{3+}$ ions [15]. Monodisperse gold nanoparticles have been synthesized by using alkalotolerant Rhodococcus sp. under extreme biological conditions like alkaline and slightly elevated temperature conditions [16]. Lengke et al. claimed the synthesis of gold nanostructures in different shapes (spherical, cubic, and octahedral) by filamentous cyanobacteria from $\mathrm{Au}(\mathrm{I})$-thiosulfate and $\mathrm{Au}(\mathrm{III})$-chloride complexes and analyzed their formation mechanisms [17, 18]. Nair and Pradeep reported the growth of nanocrystals and nanoalloys using Lactobacillus [19]. Some other typical gold nanoparticles produced by microorganisms are summarized in Table 1 [20-27].

2.1.2. Silver Nanoparticles. Silver nanoparticles, like their bulk counterpart, show effective antimicrobial activity against Gram-positive and Gram-negative bacteria, including highly multiresistant strains such as methicillinresistant Staphylococcus aureus [28]. The secrets discovered from nature have led to the development of biomimetic approaches to the growth of advanced nanomaterials. Recently, scientists have made efforts to make use of microorganisms as possible eco-friendly nanofactories for the synthesis of silver nanoparticles. Various microbes are known to reduce the $\mathrm{Ag}^{+}$ions to form silver nanoparticles, most of which are found to be spherical particles [29-31]. Klaus and coworkers have shown that the bacterium Pseudomonas stutzeri AG259, isolated from a silver mine, when placed in a concentrated aqueous solution of silver nitrate, played a major role in the reduction of the $\mathrm{Ag}^{+}$ions and the formation of silver nanoparticles (AgNPs) of well-defined size and distinct topography within the periplasmic space of the bacteria [32]. AgNPs were synthesized in the form of a film or produced in solution or accumulated on the surface of its cell when fungi, Verticillium, Fusarium oxysporum, or Aspergillus flavus, were employed [33-36]. Some other silver nanoparticles produced by microorganisms are listed in Table 1 [37-45].

2.1.3. Alloy Nanoparticles. Alloy nanoparticles are of great interest due to their applications in catalysis, electronics, as optical materials, and coatings $[46,47]$. Senapati et al. reported the synthesis of bimetallic Au-Ag alloy by $\mathrm{F}$. oxysporum and argued that the secreted cofactor NADH plays an important role in determining the composition of $\mathrm{Au}-\mathrm{Ag}$ alloy nanoparticles [46]. Zheng et al. studied Au-Ag alloy nanoparticles biosynthesized by yeast cells [47]. Fluorescence microscopic and transmission electron microscopic characterizations indicated that the Au-Ag alloy nanoparticles were mainly synthesized via an extracellular approach and generally existed in the form of irregular polyg- 
onal nanoparticles. Electrochemical investigations revealed that the vanillin sensor based on Au-Ag alloy nanoparticles modified glassy carbon electrode was able to enhance the electrochemical response of vanillin for at least five times. Sawle et al. demonstrated the synthesis of core-shell Au-Ag alloy nanoparticles from fungal strains Fusarium semitectum and showed that the nanoparticle suspensions are quite stable for many weeks [48].

2.1.4. Other Metallic Nanoparticles. Heavy metals are known to be toxic to microorganism life. In nature, microbial resistance to most toxic heavy metals is due to their chemical detoxification as well as due to energy-dependent ion efflux from the cell by membrane proteins that function either as ATPase or as chemiosmotic cation or proton antitransporters. Alteration in solubility also plays a role in microbial resistance [3]. Konishi and coworkers reported that platinum nanoparticles were achieved using the metal ion-reducing bacterium Shewanella algae [49]. Resting cells of $S$. algae were able to reduce aqueous $\mathrm{PtCl}_{6}{ }^{2-}$ ions into elemental platinum at room temperature and neutral $\mathrm{pH}$ within $60 \mathrm{~min}$ when lactate was provided as the electron donor. Platinum nanoparticles of about $5 \mathrm{~nm}$ were located in the periplasm. Sinha and Khare demonstrated that mercury nanoparticles can be synthesized by Enterobacter sp. cells [50]. The culture conditions ( $\mathrm{pH} 8.0$ and lower concentration of mercury) promote the synthesis of uniform-sized 2$5 \mathrm{~nm}$, spherical, and monodispersed intracellular mercury nanoparticles. Pyrobaculum islandicum, an anaerobic hyperthermophilic microorganism, was reported to reduce many heavy metals including $\mathrm{U}(\mathrm{VI}), \mathrm{Tc}(\mathrm{VII}), \mathrm{Cr}(\mathrm{VI}), \mathrm{Co}(\mathrm{III})$, and $\mathrm{Mn}(\mathrm{IV})$ with hydrogen as the electron donor [51]. The palladium nanoparticles could be synthesized by the sulfatereducing bacterium, Desulfovibrio desulfuricans, and metal ion-reducing bacterium, S. oneidensis [52-54]. Some other nanoparticles produced by microorganisms are also listed in Table $1[55,56]$.

2.2. Oxide Nanoparticles. Oxide nanoparticle is an important type of compound nanoparticle synthesized by microbes. In this section, we reviewed the biosynthesized oxide nanoparticles from the two aspects: magnetic oxide nanoparticles and nonmagnetic oxide nanoparticles. Most of the examples of the magnetotactic bacteria used for the production of magnetic oxide nanoparticles and biological systems for the formation of nonmagnetic oxide nanoparticles have been summarized in Table 2.

2.2.1. Magnetic Nanoparticles. Magnetic nanoparticles are recently developed new materials, due to their unique microconfiguration and properties like super paramagnetic and high coercive force, and their prospect for broad applications in biological separation and biomedicine fields. Magnetic nanoparticles like $\mathrm{Fe}_{3} \mathrm{O}_{4}$ (magnetite) and $\mathrm{Fe}_{2} \mathrm{O}_{3}$ (maghemite) are known to be biocompatible. They have been actively investigated for targeted cancer treatment (magnetic hyperthermia), stem cell sorting and manipulation, guided drug delivery, gene therapy, DNA analysis, and magnetic resonance imaging (MRI) [57].

Magnetotactic bacteria synthesize intracellular magnetic particles comprising iron oxide, iron sulfides, or both [58, 59]. In order to distinguish these particles from artificially synthesized magnetic particles (AMPs), they are referred to as bacterial magnetic particles (BacMPs) [60]. BacMPs, which are aligned in chains within the bacterium, are postulated to function as biological compass needles that enable the bacterium to migrate along oxygen gradients in aquatic environments, under the influence of the Earth's geomagnetic field [61]. BacMPs can easily disperse in aqueous solutions because they are enveloped by organic membranes that mainly consist of phospholipids and proteins. Furthermore, an individual BacMP contains a single magnetic domain or magnetite that yields superior magnetic properties [62].

Since the first report of magnetotactic bacteria in 1975 [61], various morphological types including cocci, spirilla, vibrios, ovoid bacteria, rod-shaped bacteria, and multicellular bacteria possessing unique characteristics have been identified and observed to inhabit various aquatic environments [62, 63]. Magnetotactic cocci, for example, have shown high diversity and distribution and have been frequently identified at the surface of aquatic sediments. The discovery of this bacterial type, including the only cultured magnetotactic coccus strain MC- 1 , suggested that they are microaerophilic. In the case of the vibrio bacterium, three facultative anaerobic marine vibrios-strains MV-1, MV-2, and MV-4-have been isolated from estuarine salt marshes. These bacteria have been classified as members of $\alpha$ Proteobacteria, possibly belonging to the Rhodospirillaceae family, and observed to synthesize BacMPs of a truncated hexa-octahedron shape and grow chemoorganoheterotrophically as well as chemolithoautotrophically. The members of the family Magnetospirillaceae, on the other hand, can be found in fresh water sediments. With the use of growth medium and magnetic isolation techniques established, a considerable number of the magnetotactic bacteria isolated to date have been found to be members of this family. The Magnetospirillum magnetotacticum strain MS1 was the first member of the family to be isolated [63], while the Magnetospirillum gryphiswaldense strain MSR-1 is also well studied with regard to both its physiological and genetic characteristics. Magnetospirillum magneticum AMB-1 isolated by Arakaki et al. was facultative anaerobic magnetotactic spirilla [60].

A number of new magnetotactic bacteria have been found in various aquatic environments since 2000. Some of the newly identified magnetotactic bacteria have been summarized in Table 2. Uncultured magnetotactic bacteria have been observed in numerous habitats [78]. Most known cultured magnetotactic bacteria are mesophilic and tend not to grow much above $30^{\circ} \mathrm{C}$. Uncultured magnetotactic bacteria were mostly at $30^{\circ} \mathrm{C}$ and below. There are only a few reports describing thermophilic magnetotactic bacteria. Lefèvre et al. reported that one of magnetotactic bacteria called HSMV-1 was found in samples from springs whose 
TABLE 1: Metal nanoparticles synthesized by microorganisms.

\begin{tabular}{|c|c|c|c|c|c|c|}
\hline Microorganisms & Products & $\begin{array}{c}\text { Culturing } \\
\text { temperature } \\
\left({ }^{\circ} \mathrm{C}\right)\end{array}$ & Size $(\mathrm{nm})$ & Shape & Location & References \\
\hline Sargassum wightii & $\mathrm{Au}$ & Not available & $8-12$ & planar & Extracellular & {$[20]$} \\
\hline Rhodococcus sp. & $\mathrm{Au}$ & 37 & $5-15$ & spherical & Intracellular & {$[16]$} \\
\hline Shewanella oneidensis & $\mathrm{Au}$ & 30 & $12 \pm 5$ & spherical & Extracellular & [21] \\
\hline Plectonemaboryanum & $\mathrm{Au}$ & $25-100$ & $<10-25$ & cubic & Intracellular & [17] \\
\hline $\begin{array}{l}\text { Plectonema boryanum } \\
\text { UTEX } 485\end{array}$ & $\mathrm{Au}$ & 25 & $10 \mathrm{~nm}-6 \mu \mathrm{m}$ & octahedral & Extracellular & {$[18]$} \\
\hline Candida utilis & $\mathrm{Au}$ & 37 & Not available & Not available & Intracellular & [22] \\
\hline V. luteoalbum & $\mathrm{Au}$ & 37 & Not available & Not available & Intracellular & {$[22]$} \\
\hline Escherichia coli & $\mathrm{Au}$ & 37 & $20-30$ & Triangles, hexagons & Extracellular & {$[23]$} \\
\hline Yarrowia lipolytica & $\mathrm{Au}$ & 30 & 15 & Triangles & Extracellular & {$[24]$} \\
\hline $\begin{array}{l}\text { Pseudomonas } \\
\text { aeruginosa }\end{array}$ & $\mathrm{Au}$ & 37 & $15-30$ & Not available & Extracellular & {$[25]$} \\
\hline $\begin{array}{l}\text { Rhodopseudomonas } \\
\text { capsulate }\end{array}$ & $\mathrm{Au}$ & 30 & $10-20$ & Spherical & Extracellular & {$[26]$} \\
\hline Shewanella algae & $\mathrm{Au}$ & 25 & $10-20$ & Not available & Intracellular & [27] \\
\hline Brevibacterium casei & $\mathrm{Au}, \mathrm{Ag}$ & 37 & $10-50$ & Spherical & Intracellular & {$[37]$} \\
\hline Trichoderma viride & $\mathrm{Ag}$ & 27 & $5-40$ & Spherical & Extracellular & {$[31]$} \\
\hline $\begin{array}{l}\text { Phaenerochaete } \\
\text { chrysosporium }\end{array}$ & $\mathrm{Ag}$ & 37 & 50-200 & Pyramidal & Extracellular & {$[39]$} \\
\hline Bacillus licheniformis & Ag & 37 & 50 & Not available & Extracellular & {$[40]$} \\
\hline Escherichia coli & Ag & 37 & 50 & Not available & Extracellular & {$[41]$} \\
\hline $\begin{array}{l}\text { Corynebacterium } \\
\text { glutamicum }\end{array}$ & $\mathrm{Ag}$ & 30 & $5-50$ & Irregular & Extracellular & {$[42]$} \\
\hline Trichoderma viride & $\mathrm{Ag}$ & $10-40$ & $2-4$ & Not available & Extracellular & {$[43]$} \\
\hline $\begin{array}{l}\text { Ureibacillus } \\
\text { thermosphaericus }\end{array}$ & $\mathrm{Au}$ & $60-80$ & $50-70$ & Not available & Extracellular & {$[44]$} \\
\hline Bacillus cereus & $\mathrm{Ag}$ & 37 & $4-5$ & Spherical & Intracellular & {$[45]$} \\
\hline Aspergillus flavus & $\mathrm{Ag}$ & 25 & $8.92 \pm 1.61$ & Spherical & Extracellular & {$[34]$} \\
\hline Aspergillus fumigatus & $\mathrm{Ag}$ & 25 & $5-25$ & Spherical & Extracellular & {$[35]$} \\
\hline Verticillium sp. & Ag & 25 & $25 \pm 8$ & Spherical & Extracellular & {$[36]$} \\
\hline Fusarium oxysporum & $\mathrm{Ag}$ & 25 & $5-50$ & Spherical & Extracellular & {$[36]$} \\
\hline Neurospora crassa & $\mathrm{Au}, \mathrm{Au} / \mathrm{Ag}$ & 28 & $32,20-50$ & Spherical & $\begin{array}{l}\text { Intracellular, } \\
\text { extracellular }\end{array}$ & {$[38]$} \\
\hline Shewanella algae & $\mathrm{Pt}$ & 25 & 5 & Not available & Intracellular & {$[49]$} \\
\hline Enterobacter $s p$ & $\mathrm{Hg}$ & 30 & $2-5$ & Spherical & Intracellular & {$[50]$} \\
\hline Shewanella sp & $\mathrm{Se}$ & 30 & $181 \pm 40$ & Spherical & Extracellular & {$[55]$} \\
\hline Escherichia coli & $\mathrm{CdTe}$ & 37 & $2.0-3.2$ & Spherical & Extracellular & {$[56]$} \\
\hline yeast & $\mathrm{Au} / \mathrm{Ag}$ & 30 & $9-25$ & Irregular polygonal & Extracellular & {$[47]$} \\
\hline Fusarium oxysporum & Au-Ag alloy & 25 & $8-14$ & Spherical & Extracellular & {$[46]$} \\
\hline $\begin{array}{l}\text { Pyrobaculum } \\
\text { islandicum }\end{array}$ & $\begin{array}{l}\mathrm{U}(\mathrm{VI}), \mathrm{Tc}(\mathrm{VII}), \\
\mathrm{Cr}(\mathrm{VI}), \mathrm{Co}(\mathrm{III}), \\
\mathrm{Mn}(\mathrm{IV})\end{array}$ & 100 & N/A & Spherical & Extracellular & {$[51]$} \\
\hline $\begin{array}{l}\text { Desulfovibrio } \\
\text { desulfuricans }\end{array}$ & $\mathrm{Pd}$ & 25 & 50 & Spherical & Extracellular & {$[52]$} \\
\hline
\end{tabular}

temperatures ranged from 32 to $63^{\circ} \mathrm{C}$ [71]. TEM images of unstained cell of HSMV-1 showed a single polar flagellum and a single chain of bullet-shaped magnetosomes. The average number of magnetosome crystals per cell is 12 \pm 6 with an average size of $113 \pm 34 \mathrm{~nm}$ by $40 \pm$ $5 \mathrm{~nm}$. The results from the paper clearly showed that some magnetotactic bacteria can be considered at least moderately thermophilic. They extended the upper temperature limit 
TABLE 2: Oxide nanoparticles synthesized by microorganisms.

\begin{tabular}{|c|c|c|c|c|c|c|}
\hline Microorganisms & Products & $\begin{array}{c}\text { Culturing } \\
\text { temperature } \\
\left({ }^{\circ} \mathrm{C}\right)\end{array}$ & Size $(\mathrm{nm})$ & Shape & Location & References \\
\hline $\begin{array}{l}\text { Shewanella } \\
\text { oneidensis }\end{array}$ & $\mathrm{Fe}_{3} \mathrm{O}_{4}$ & 28 & $40-50$ & $\begin{array}{c}\text { Rectangular, rhombic, } \\
\text { hexagonal }\end{array}$ & Extracellular & [64] \\
\hline QH-2 & $\mathrm{Fe}_{3} \mathrm{O}_{4}$ & $22-26$ & $81 \pm 23 \times 58 \pm 20$ & Rectangular & Intracellular & {$[65]$} \\
\hline $\begin{array}{l}\text { Recombinant } \\
\text { AMB-1 }\end{array}$ & $\mathrm{Fe}_{3} \mathrm{O}_{4}$ & 28 & 20 & Cubo-octahedral & Intracellular & {$[66]$} \\
\hline Yeast cells & $\mathrm{Fe}_{3} \mathrm{O}_{4}$ & 36 & Not available & Wormhole-like & Extracellular & {$[67]$} \\
\hline Yeast cells & $\mathrm{FePO}_{4}$ & 36 & Not available & Nanopowders & Extracellular & {$[68]$} \\
\hline WM-1 & $\mathrm{Fe}_{3} \mathrm{O}_{4}$ & 28 & $54 \pm 12.3 \times 43 \pm 10.9$ & Cuboidal & Intracellular & {$[69]$} \\
\hline $\begin{array}{l}\text { Shewanella } \\
\text { oneidensis MR-1 }\end{array}$ & $\mathrm{Fe}_{2} \mathrm{O}_{3}$ & 25 & $30-43$ & $\begin{array}{l}\text { Pseudohexagonal/irregular } \\
\text { or rhombohedral }\end{array}$ & Intracellular & {$[70]$} \\
\hline HSMV-1 & $\mathrm{Fe}_{3} \mathrm{O}_{4}$ & 63 & $113 \pm 34 \times 40 \pm 5$ & Bullet-shaped & Intracellular & {$[71]$} \\
\hline $\begin{array}{l}\text { Saccharomyces } \\
\text { cerevisiae }\end{array}$ & $\mathrm{Sb}_{2} \mathrm{O}_{3}$ & $25-60$ & $2-10$ & Spherical & Intracellular & {$[72]$} \\
\hline Lactobacillus sp. & $\mathrm{BaTiO}_{3}$ & 25 & $20-80$ & Tetragonal & Extracellular & {$[73]$} \\
\hline Lactobacillus sp. & $\mathrm{TiO}_{2}$ & 25 & $8-35$ & Spherical & Extracellular & {$[74]$} \\
\hline $\begin{array}{l}\text { Fusarium } \\
\text { oxysporum }\end{array}$ & $\mathrm{TiO}_{2}$ & 300 & $6-13$ & Spherical & Extracellular & {$[75]$} \\
\hline $\begin{array}{l}\text { Fusarium } \\
\text { oxysporum }\end{array}$ & $\mathrm{BaTiO}_{3}$ & 25 & $4-5$ & Spherical & Extracellular & {$[76]$} \\
\hline $\begin{array}{l}\text { Fusarium } \\
\text { oxysporum }\end{array}$ & $\mathrm{ZrO}_{2}$ & 25 & $3-11$ & Spherical & Extracellular & [77] \\
\hline
\end{tabular}

for environments where magnetotactic bacteria exist and likely grow $\left(\sim 63^{\circ} \mathrm{C}\right)$ and where magnetosome magnetite is deposited [71]. Zhou et al. reported that magnetic $\mathrm{Fe}_{3} \mathrm{O}_{4}$ materials with mesoporous structure were synthesized by coprecipitation method using yeast cells as a template [67, $68]$. Some other magnetic oxide nanoparticles are listed in Table $2[64-66,69,70]$.

2.2.2. Nonmagnetic Oxide Nanoparticles. Beside magnetic oxide nanoparticles, other oxide nanoparticles have also been studied including $\mathrm{TiO}_{2}, \mathrm{Sb}_{2} \mathrm{O}_{3}, \mathrm{SiO}_{2}, \mathrm{BaTiO}_{3}$, and $\mathrm{ZrO}_{2}$ nanoparticles [72-77, 96]. Jha and co-workers found a green low-cost and reproducible Saccharomyces cerevisiae mediated biosynthesis of $\mathrm{Sb}_{2} \mathrm{O}_{3}$ nanoparticles [72]. The synthesis was performed akin to room temperature. Analysis indicated that $\mathrm{Sb}_{2} \mathrm{O}_{3}$ nanoparticles unit was a spherical aggregate having a size of $2-10 \mathrm{~nm}$ [72]. Bansal et al. used F. oxysporum (Fungus) to produce $\mathrm{SiO}_{2}$ and $\mathrm{TiO}_{2}$ nanoparticles from aqueous anionic complexes $\mathrm{SiF}_{6}{ }^{2-}$ and $\mathrm{TiF}_{6}{ }^{2-}$, respectively [75]. They also prepared tetragonal $\mathrm{BaTiO}_{3}$ and quasispherical $\mathrm{ZrO}_{2}$ nanoparticles from $F$. oxysporum with a size range of $4-5 \mathrm{~nm}$ and $3-11 \mathrm{~nm}$, respectively $[76,77]$.

2.3. Sulfide Nanoparticles. In addition to oxide nanoparticles, sulfide nanoparticles have also attracted great attention in both fundamental research and technical applications as quantum-dot fluorescent biomarkers and cell labeling agents because of their interesting and novel electronic and optical properties [97]. CdS nanocrystal is one typical type of sulfide nanoparticle and has been synthesized by microorganisms. Cunningham and Lundie found that Clostridium thermoaceticum could precipitate $\mathrm{CdS}$ on the cell surface as well as in the medium from $\mathrm{CdCl}_{2}$ in the presence of cysteine hydrochloride in the growth medium where cysteine most probably acts as the source of sulfide [98]. Klebsiella pneumoniae exposed to $\mathrm{Cd}^{2+}$ ions in the growth medium were found to form $20-200 \mathrm{~nm}$ CdS on the cell surface [99]. Intracellular CdS nanocrystals, composed of a wurtzite crystal phase, are formed when Escherichia coli is incubated with $\mathrm{CdCl}_{2}$ and $\mathrm{Na}_{2} \mathrm{SO}_{4}$ [83]. Nanocrystal formation varies dramatically depending on the growth phase of the cells and increases about 20-fold in E. coli grown in the stationary phase compared to that grown in the late logarithmic phase. Dameron et al. have used S. pombe and C. glabrata (yeasts) to produce intracellular CdS nanoparticles with cadmium salt solution [85]. ZnS and PbS nanoparticles were successfully synthesized by biological systems. Rhodobacter sphaeroides and Desulfobacteraceae have been used to obtain ZnS nanoparticles intracellularly with $8 \mathrm{~nm}$ and $2-5 \mathrm{~nm}$ in average diameter, respectively $[86,87]$. PbS nanoparticles were also synthesized by using Rhodobacter sphaeroides, whose diameters were controlled by the culture time [88]. Ahmad et al. have found Eukaryotic organisms such as fungi to be a good candidate for the synthesis of metal sulfide nanoparticles extracellularly [89]. Some stable metal sulfide nanoparticles, such as $\mathrm{CdS}, \mathrm{ZnS}, \mathrm{PbS}$, and $\mathrm{MoS}_{2}$, can be produced extracellularly by the fungus $F$. oxysporum when exposed to aqueous solution of metal sulfate. The quantum dots were formed by the reaction of $\mathrm{Cd}^{2+}$ ions with sulfide 
ions which were produced by the enzymatic reduction of sulfate ions to sulfide ions.

Another kind of sulfide nanoparticle was magnetic $\mathrm{Fe}_{3} \mathrm{~S}_{4}$ or FeS nanoparticle. Bazylinski et al. reported the formation of $\mathrm{Fe}_{3} \mathrm{~S}_{4}$ by uncultured magnetotactic bacteria [59]. They examined a sediment sample that contained approximately $1 \times 10^{5}$ magnetotactic bacteria per $\mathrm{cm}^{3}$, and approximately $10^{5}$ cells were obtained after purification by the racetrack method. Magnetosomes in the uncultured cells exhibited elongated rectangular shape. The average magnetosome number per cell was approximately 40 , and they were mainly located as a large cluster within the cell. Aligned magnetosomes forming a chainlike structure were also observed beside the large cluster. Sulfate-reducing bacteria were capable of producing magnetic FeS nanoparticles [90]. Some other sulfide nanoparticles produced by microorganisms are summarized in Table 3 [79-84].

2.4. Other Nanoparticles. In biological systems, a large variety of organisms form organic/inorganic composites with ordered structures by the use of biopolymers such as protein and microbe cells. In addition to nanoparticles mentioned above, $\mathrm{PbCO}_{3}, \mathrm{CdCO}_{3}, \mathrm{SrCO}_{3}, \mathrm{PHB}, \mathrm{Zn}_{3}\left(\mathrm{PO}_{4}\right)_{2}$, and CdSe nanoparticles were reported to be synthesized by microbes (Table 4) [91-95]. $\mathrm{SrCO}_{3}$ crystals were obtained when challenging fungi were incubated with aqueous $\mathrm{Sr}^{2+}$ ions [92]. The authors believed that secretion of proteins during growth of the fungus Fusarium oxysporum is responsible for modulating the morphology of strontianite crystals and directing their hierarchical assembly into higherorder superstructures. Zinc phosphate nanopowders were synthesized with yeasts as biotemplates [93]. Yan et al. demonstrated the synthesis of $\mathrm{Zn}_{3}\left(\mathrm{PO}_{4}\right)_{2}$ powders with butterfly-like microstructure with a size range of $10-80 \mathrm{~nm}$ in width and $80-200 \mathrm{~nm}$ in length [94]. Kumar et al. showed that highly luminescent CdSe quantum dots can be synthesized by F. oxysporum at room temperature [95].

2.5. Mechanisms of Nanoparticle Formation by Microorganisms. Different microorganisms have different mechanisms of forming nanoparticles. However, nanoparticles are usually formed following this way: metal ions are first trapped on the surface or inside of the microbial cells. The trapped metal ions are then reduced to nanoparticles in the presence of enzymes. In general, microorganisms impact the mineral formation in two distinct ways. They can modify the composition of the solution so that it becomes supersaturated or more supersaturated than it previously was with respect to a specific phase. A second means by which microorganisms can impact mineral formation is through the production of organic polymers, which can impact nucleation by favoring (or inhibiting) the stabilization of the very first mineral seeds [100]. This section reviewed the possible formation mechanisms for some typical nanoparticles: gold and silver nanoparticles, heavy metallic nanoparticles, magnetic nanoparticles, and sulfide nanoparticles.

The exact mechanism for the intracellular formation of gold and silver nanoparticles by Verticillium sp. or algal biomass was not fully understood. But the fact that nanoparticles were formed on the surface of the mycelia and not in the solution supports the following hypothesis: the gold or silver ions were first trapped on the surface of the fungal cells via electrostatic interaction between the ions and negatively charged cell wall from the carboxylate groups in the enzymes. Next, the enzymes reduced the metal ions to form gold or silver nuclei, which subsequently grow through further reduction and accumulation [42]. Kalishwaralal and co-workers speculated that the nitrate reductase enzyme is involved in the synthesis of silver nanoparticles in $B$. licheniformis [101]. This enzyme is induced by nitrate ions and reduces silver ions to metallic silver. The possible mechanism that may involve the reduction of silver ions is the electron shuttle enzymatic metal reduction process. $\mathrm{NADH}$ and NADH-dependent nitrate reductase enzymes are important factors in the biosynthesis of metal nanoparticles. $B$. licheniformis is known to secrete the cofactor $\mathrm{NADH}$ and $\mathrm{NADH}$-dependent enzymes, especially nitrate reductase, which might be responsible for the bioreduction of $\mathrm{Ag}^{+}$to $\mathrm{Ag}^{0}$ and the subsequent formation of silver nanoparticles [25].

The formation of heavy metallic nanoparticles can be attributed to the metallophilic microorganism's developed genetic and proteomic responses to toxic environments [102]. Heavy metal ions, for example, $\mathrm{Hg}^{2+}, \mathrm{Cd}^{2+}, \mathrm{Ag}^{+}$, $\mathrm{Co}^{2+}, \mathrm{CrO}_{4}{ }^{2+}, \mathrm{Cu}^{2+}, \mathrm{Ni}^{2+}, \mathrm{Pb}^{2+}$, and $\mathrm{Zn}^{2+}$, cause toxic effects to the survival of microorganisms. To counter these effects, microorganisms have developed genetic and proteomic responses to strictly regulate metal homeostasis [103]. Microorganisms harbor numerous metal resistance gene clusters enabling cell detoxification via a number of mechanisms such as complexation, efflux, or reductive precipitation. Hence metallophilic bacteria thrive in environments containing high concentrations of mobile heavy metal ions, such as mine waste rock piles, efflux streams of metal processing plants, and naturally mineralized zones [104].

The molecular mechanism of BacMP biomineralization is hypothesized to be a multistep process [60]. The first step involves the invagination of the cytoplasmic membrane, and the vesicle formed serves as the precursor of the BacMP membrane. The mechanism of envelope formation, however, still remains unclear. It is most probable that the mechanisms of vesicle formation for magnetotactic bacteria are similar to most eukaryotes and that a specific GTPase mediates the priming of the invagination. The formed vesicles were then assembled into a linear chain along with cytoskeletal filaments. The second step of BacMP biomineralization involves the accumulation of ferrous ions into the vesicles by the transmembrane iron transporters. External iron is internalized by transport proteins and siderophores. The internal iron is controlled strictly by an oxidation-reduction system. In the final step, tightly bound BacMP proteins trigger magnetite crystal nucleation and/or regulate morphology. Various proteins associated with the BacMP membrane could play functional roles involved in magnetite generation. These include the accumulation of supersaturating iron concentrations, maintenance of reductive conditions and the 
TABLE 3: Sulfide nanoparticles synthesized by microorganisms.

\begin{tabular}{|c|c|c|c|c|c|c|}
\hline Microorganisms & Products & $\begin{array}{l}\text { Culturing } \\
\text { temperature } \\
\left({ }^{\circ} \mathrm{C}\right)\end{array}$ & Size $(\mathrm{nm})$ & Shape & Location & References \\
\hline $\begin{array}{l}\text { Multicellular } \\
\text { Prokaryotes }\end{array}$ & $\mathrm{Fe}_{3} \mathrm{~S}_{4}$ & 25 & Not available & Not available & Intracellular & {$[78]$} \\
\hline $\begin{array}{l}\text { Uncultured } \\
\text { Magnetotactic } \\
\text { Bacterium }\end{array}$ & $\begin{array}{c}\text { Probably } \\
\text { polyphosphate }\end{array}$ & Not available & Not available & Rectangular & Extracellular & [79] \\
\hline $\begin{array}{l}\text { Rhodopseudomonas } \\
\text { palustris }\end{array}$ & CdS & 30 & 8 & Cubic & Intracellular & {$[80]$} \\
\hline Coriolus versicolor & CdS & 25 & $100-200$ & Spherical & Extracellular & [81] \\
\hline Lactobacillus & CdS & $25-60$ & $4.9 \pm 0.2$ & Spherical & Intracellular & {$[82]$} \\
\hline Yeast & CdS & $25-60$ & $3.6 \pm 0.2$ & Spherical & Intracellular & {$[82]$} \\
\hline E. coli & CdS & 25 & $2-5$ & Wurtzite crystal & Intracellular & [83] \\
\hline $\begin{array}{l}\text { Schizosaccharomyces } \\
\text { pombe }\end{array}$ & CdS & Not available & $1-1.5$ & Hexagonal lattice & Intracellular & {$[84]$} \\
\hline $\begin{array}{l}\text { Schizosaccharomyces } \\
\text { pombe and Candida } \\
\text { glabrata }\end{array}$ & CdS & Not available & 2 & Hexagonal lattice & Intracellular & {$[85]$} \\
\hline $\begin{array}{l}\text { Rhodobacter } \\
\text { sphaeroides }\end{array}$ & CdS & Not available & 8 & Hexagonal lattice & Intracellular & [86] \\
\hline Desulfobacteraceae & CdS & Not available & $2-5$ & Hexagonal lattice & Intracellular & [87] \\
\hline $\begin{array}{l}\text { Rhodobacter } \\
\text { sphaeroides }\end{array}$ & $\mathrm{ZnS}$ & Not available & $10.5 \pm 0.15$ & Spherical & Extracellular & {$[88]$} \\
\hline Fusarium oxysporum & CdS & Not available & $5-20$ & Spherical & Extracellular & [89] \\
\hline $\begin{array}{l}\text { Sulfate-reducing } \\
\text { bacteria }\end{array}$ & $\mathrm{FeS}$ & Not available & 2 & Spherical & Extracellular & {$[90]$} \\
\hline
\end{tabular}

TABLE 4: Other miscellaneous nanoparticles synthesized by microorganisms.

\begin{tabular}{lcccccc}
\hline Microorganisms & Products & $\begin{array}{c}\text { Culturing } \\
\text { temperature } \\
\left({ }^{\circ} \mathrm{C}\right)\end{array}$ & Size $(\mathrm{nm})$ & Shape & Location & References \\
\hline $\begin{array}{l}\text { Fusarium } \\
\text { oxysporum }\end{array}$ & $\mathrm{PbCO}_{3}, \mathrm{CdCO}_{3}$ & 27 & $120-200$ & Spherical & Extracellular & {$[91]$} \\
$\begin{array}{l}\text { Fusarium } \\
\text { oxysporum }\end{array}$ & $\mathrm{SrCO}_{3}$ & 27 & $10-50$ & Needlelike & Extracellular & {$[92]$} \\
$\begin{array}{l}\text { Brevibacterium } \\
\text { casei }\end{array}$ & $\mathrm{PHB}$ & 37 & $100-125$ & Not available & Intracellular & {$[93]$} \\
$\begin{array}{l}\text { Yeasts } \\
\begin{array}{l}\text { Fusarium } \\
\text { oxysporum }\end{array}\end{array}$ & $\mathrm{Zn}_{3}\left(\mathrm{PO}_{4}\right)_{2}$ & 25 & $10-80 \times 80-200$ & Rectangular & Extracellular & {$[94]$} \\
\hline
\end{tabular}

oxidation of iron to induce mineralization, or the partial reduction and dehydration of ferrihydrite to magnetite [60].

Another possible mechanism for the synthesis of magnetites using Shewanella oneidensis, which consists of both passive and active mechanisms, was recently suggested by Perez-Gonzalez and coworkers [64]. First, active production of $\mathrm{Fe}^{2+}$ occurs when bacteria utilize ferrihydrite as a terminal electron acceptor, and the $\mathrm{pH}$ value surrounding the cells rises probably due to the bacterial metabolism of amino acids. Then, through a passive mechanism, the localized concentration of $\mathrm{Fe}^{2+}$ and $\mathrm{Fe}^{3+}$ at the net negatively charged cell wall, cell structures, and/or cell debris induces a local rise of supersaturation of the system with respect to magnetite, causing the magnetite phase to precipitate.

Sanghi and Verma proposed that the formation of CdS NPs is through disulfide (cystine) bridges and may be attributed to cleavage of $\mathrm{S}-\mathrm{H}$ bond and formation of a new bond, that is, $-\mathrm{S}-\mathrm{Cd}$ bond of Cd-thiolate (Cd-S$\mathrm{CH}_{2} \mathrm{COOH}$ ) complex on the nanoparticle surface [81]. The $-\mathrm{COOH}$ groups from the cadmium-thiolate complexes do not react with the $-\mathrm{NH}_{2}$ groups of protein but interact with hydrogen bond. Therefore, the capped CdS nanoparticles are bonded to $-\mathrm{NH}_{2}$ groups by hydrogen bond [105]. One of 
the oxygen atoms of the carboxylic group $(-\mathrm{COOH})$ formed the coordinate bond between the oxygen atom and $\mathrm{Cd}^{2+}$ ions [106], thus competing with the thiol group to assemble onto the surfaces of the CdS nanoparticles.

2.6. Control of Size and Morphology of Nanoparticles. It is well known that the electronic and optical properties of nanoparticles are heavily dependent on their size and shape. Thus, there has been tremendous interest in controlling the size, shape, and surrounding media of nanoparticles. Particular emphasis has recently been placed on the control of shape, because in many cases it allows properties to be fine-tuned with a great versatility that gives the particles a unique nature. Despite that the physical and chemical methods are able to produce large quantities of nanoparticles with a defined size and shape in a relatively short time, these methods are complicated and have certain drawbacks such as producing hazardous toxic wastes that are harmful, not only to the environment but also to human health. Microbes, which are regarded as potent eco-friendly green nanofactories, have the potential to control the size and shape of biological nanoparticles.

Gericke and Pinches found that the intracellular synthesis of gold nanoparticles of various morphologies and sizes could be obtained in two fungal cultures [22], $V$. luteoalbum and another named Isolate 6-3. The rate of particle formation and the particle size could, to an extent, be manipulated by controlling parameters such as $\mathrm{pH}$, temperature, gold concentration, and exposure time to $\mathrm{AuCl}_{4}{ }^{-}$. Various particle morphologies including spherical, triangular, hexagonal, and other shapes were present, as revealed by scanning electron microscopy. Large variations in particle size were observed and particle size varied from a few nanometers to approximately $100 \mathrm{~nm}$ in diameter. Their results also suggested that the spherical particles tended to be smaller than the hexagonal- and triangular-shaped particles. The bacterial cultures screened during the study tended to synthesize small, relatively uniform-sized gold nanoparticles intracellularly. The particles were observed mainly in the cytoplasm of the cells, and the majority of the particles were spherical in shape.

Gurunathan et al. studied optimum reaction conditions for maximum synthesis of AgNPs and reduction in particle size [41]. To find the optimum conditions, different medium and medium of varying concentrations of $\mathrm{AgNO}_{3}$, reaction temperatures and $\mathrm{pH}$ values were used in the synthesis of AgNPs. The medium contributing to the maximum synthesis was found to be a nitrate medium at a concentration of $5 \mathrm{mMAgNO}_{3}$, a reaction temperature of $60^{\circ} \mathrm{C}$, and a $\mathrm{pH}$ value of 10.0 . Under these optimum conditions, only $30 \mathrm{~min}$ was required to obtain over $95 \%$ conversion using the culture supernatant of E. coli. This is comparable to or faster than the synthesis rate of similar particles obtained using chemical methods. The average particle size could be tuned from $10-90 \mathrm{~nm}$ by varying the $\mathrm{AgNO}_{3}$ concentration, reaction temperature, and $\mathrm{pH}$.

On the synthesis of Pt nanoparticles, Riddin and coworkers found that in the absence of the spatial restrictions of the cell wall, the cell-soluble extract (CSE) was able to reduce $\mathrm{Pt}(\mathrm{IV})$ to form nanoparticles, which are stabilized in solution by bound proteins and exhibit both geometric and irregular morphologies [107]. It appeared that high initial $\mathrm{Pt}(\mathrm{IV})$ concentrations resulted in particles that were more regular and geometric in nature. At high initial $\mathrm{Pt}(\mathrm{IV})$ concentrations, more hydrochloride was generated $(\mathrm{pH} \leq$ 4) within the system, resulting in the precipitation of the nanoparticle-protein bioconjugates and the subsequent decrease of the number of soluble particles present in the colloid. Furthermore, they demonstrated that proteinstabilized biogenic $\operatorname{Pt}(0)$ nanoparticles with a great variation in size and shape can be synthesized in the absence of the cellular restrictions.

Magnetotactic bacteria produce iron oxide magnetic particles with uniform sizes and morphologies. Magnetites formed by magnetotactic bacteria take various shapes such as cuboids, bullet-shaped, rhombic, and rectangular. Various crystal morphologies and compositions have been observed that are species or strain dependent, indicating the presence of a high degree of biological control [66].

Arakaki et al. found that Mms6 is a dominant protein that tightly associates with the surface of bacterial magnetites in Magnetospirillum magneticum AMB-1 [108]. The protein was showed to mediate the formation of uniform magnetite crystals of cubo-octahedral morphology. Magnetite formation was investigated using synthetic peptides mimicking the Mms6 protein. Particles synthesized in the presence of short peptides harboring the C-terminal acidic region of Mms6 exhibited a spherical morphology with circularities of 0.70 0.90 , similar to those of bacterial magnetites and particles formed in the presence of the Mms6 protein. In contrast, a rectangular morphology with circularities of $0.60-0.85$ was obtained when other peptides were used in synthesis [108].

The same group introduced another method for the highly regulated synthesis of magnetite crystals at reduced temperatures in aqueous solution using recombinant magnetotactic bacterial protein Mms6. Crystallographic analysis of the magnetite crystals indicates that Mms6 mediates the formation of magnetite particles with a specific crystal shape and narrow size distribution similar to those observed in magnetic bacteria. Mms6 aggregates in aqueous solution, has a strong affinity for iron ions, and contains a sequence motif similar to several biomineralization scaffold proteins in other organisms. The crystals exhibit similar sizes $(20 \mathrm{~nm})$ and morphologies (cubo-octahedral), as opposed to crystals formed in the absence of Mms6. This suggests that Mms6 has a strong effect in regulating the size and shape of nanoparticles during the synthesis process [66].

The control of particle size has also been demonstrated for other nanoparticles. For example, Yan et al. found that the inducing of yeasts is an effective way to obtain zinc phosphate powders with narrow size distribution in diameter [94]. Their method utilized the function of the yeasts in the reaction system to inhibit the excess agglomeration of $\mathrm{Zn}_{3}\left(\mathrm{PO}_{4}\right)_{2}$ crystals to effectively control the particle size and size distribution. 


\section{Applications of Nanoparticles}

Nanomedicine is a burgeoning field of research with tremendous prospects for the improvement of the diagnosis and treatment of human diseases [109]. Dispersed nanoparticles are usually employed in nanobiomedicine as fluorescent biological labels $[110,111]$, drug and gene delivery agents [112, 113], and in applications such as biodetection of pathogens [114], tissue engineering $[115,116]$, tumor destruction via heating (hyperthermia) [117], MRI contrast enhancement [118], and phagokinetic studies [119].

A plethora of reviews and research papers studying the applications of nanoparticle in biomedicine have been published [120-129]. While the field of biosynthesized nanoparticles is relatively new, researchers have already started exploring their use in applications such as targeted drug delivery, cancer treatment, gene therapy and DNA analysis, antibacterial agents, biosensors, enhancing reaction rates, separation science, and MRI. Here, we provide some examples to illustrate these applications.

3.1. Drug Delivery. Delivering the drugs precisely and safely to their target sites at the right time to have a controlled release and achieve the maximum therapeutic effect is a key issue in the design and development of novel drug delivery systems. Targeted nanocarriers must navigate through blood-tissue barriers to reach target cells. They must enter target cells to contact cytoplasmic targets via specific endocytotic and transcytotic transport mechanisms across cellular barriers [109].

Because of their small size, nanoparticle drug carriers can bypass the blood-brain barrier and the tight epithelial junctions of the skin that normally impede delivery of drugs to the desired target site. Secondly, as a result of their high surface area to volume ratio, nanocarriers show improved pharmacokinetics and biodistribution of therapeutic agents and thus minimize toxicity by their preferential accumulation at the target site [123]. They improve the solubility of hydrophobic compounds and render them suitable for parenteral administration. Furthermore, they increase the stability of a variety of therapeutic agents like peptides and oligonucleotides [120].

Magnetic nanoparticles like $\mathrm{Fe}_{3} \mathrm{O}_{4}$ (magnetite) and $\mathrm{Fe}_{2} \mathrm{O}_{3}$ (maghemite) are known to be biocompatible. They have been actively investigated for targeted cancer treatment (magnetic hyperthermia), stem cell sorting and manipulation, guided drug delivery, gene therapy and DNA analysis, and MRI [57]. Xiang L. et al. evaluated the toxicity of magnetosomes from Magnetospirillum gryphiswaldense to mouse fibroblasts in vitro and found that the purified and sterilized magnetosomes were not toxic to mouse fibroblasts in vitro [129]. Meng et al. recently studied the influence of native bacterial magnetic particles on mouse immune response [130]. In their experiment, ovalbumin was used as an antigen, mixed with complete Freund's adjuvant, BacMps, and phosphate buffer solution, to immunize BALB/C mouse. After 14 days, the titers of the antiovalbumin (IgG) and subtype (IgG1, IgG2), the proliferation ability of T lymphocyte, and the expression of IL-2, IL4, IL-10, and IFN-gamma were detected. The results showed that native BMPs do not have significant influence on mouse immune response and magnetosomes have the potential to be used as novel drug or gene carriers for tumor therapy. In another study, Sun et al. loaded doxorubicin (DOX) onto bacterial magnetosomes (BMs) through covalent attachment and evaluated the ability of these particles to inhibit tumor growth [131]. In this study performed on H22 tumor-bearing mice, these DOXloaded BMs showed a comparable tumor suppression rate to DOX alone ( $86.8 \%$ versus $78.6 \%)$, but with much lower cardiac toxicity. Although, in this preliminary study, the particles were administrated subcutaneously into the solid tumor, the potential exists to magnetically manipulate these drug-loaded BMs, making them accumulate and execute therapeutic effects only at the disease sites.

Regarding the biocompatibility and pharmacokinetics of $\mathrm{BMs}$, Sun et al. studied the distribution of BMs in dejecta, urine, serum, and main organs when BMs were injected into the sublingual vena of Sprague-Dawley (SD) rats [132]. They obtained BMs of high purity and narrow size-distribution using an effective method for purification and sterilization of BMs. Their results showed that BMs were only found in livers and there was no obvious evidence to indicate the existence of BMs in the dejecta and urine within $72 \mathrm{~h}$ following the intravenous administration [132].

Magnetotactic bacteria (MTB) MC-1 with magnetosomes was also used as drug delivery agent. Felfoul et al. applied magnetotaxis to change the direction of each MTB embedded with combination of nanoparticles magnetite and the flagella to steer in small-diameter blood vessels [133]. However, in order to guide these MTBs towards a target, it is essential to be able to image these living bacteria in vivo using an existing medical imaging modality. It was shown that the magnetosomes embedded in each MTB can be used to track the displacement of these bacteria using an MRI system, since these magnetosomes disturb the local magnetic field affecting $T_{1}$ and $T_{2}$ relaxation times during MRI. Magnetic resonance, $T_{1}$-weighted and $T_{2}$-weighted images, as well as $T_{2}$ relaxivity of MTB are studied in order to validate the possibility of monitoring MTB drug delivery operations using a clinical MR scanner. It was found that MTB affect the $T_{2}$ relaxation rate much more than the $T_{1}$ relaxation rate and it can be thought as a negative contrast agent. As the signal decay in the $T_{2}$-weighted images was found to change proportionally to the bacterial concentration, a detection limit of $2.2 \times 10^{7}$ cells $/ \mathrm{mL}$ for bacterial concentration was achieved using a $T_{2}$-weighted image.

Xie et al. reported their efforts to utilize MTB-NPs for gene delivery, in which they managed to use PEI-associated MTB-NPs to deliver $\beta$-galactosidase plasmids, at both in vitro and in vivo levels [134]. They concluded in their work that such MTB-PEI-NP systems are more efficient and less toxic compared with PEI alone.

Gold and its compounds have long been used as medicinal agents throughout the history of civilization with its earliest record dating back to 5000 years ago in Egypt [135-139]. In addition to a high surface-to-volume ratio, AuNPs have unique size- and shape-dependent optical and electronic properties. The surfaces of AuNPs can also be 
readily modified with ligands containing functional groups such as thiols, phosphines, and amines, which exhibit affinity for gold surfaces [139]. Gold nanoparticles have emerged as a promising scaffold for drug and gene delivery that provide a useful complement to more traditional delivery vehicles. The combination of low inherent toxicity, high surface area, stability, and function tunability provides them with unique attributes that should enable new delivery strategies. Biomedical applications of chemically synthesized AuNPs were studied before $[138,139]$, but to our best knowledge there are no reports on the use of biosynthesized AuNPs for drug delivery.

Silver nanoparticles have been widely used as a novel therapeutic agent extending its use as antibacterial, antifungal, antiviral and antiinflammatory agent. Kalishwaralal et al. found silver nanoparticles, produced by Bacillus licheniformis, have the potential of anti-angiogenic [140]. Bovine retinal endothelial cells (BRECs) were treated with different concentrations of silver nanoparticles for $24 \mathrm{~h}$ in the presence and absence of vascular endothelial growth factor (VEGF), where $500 \mathrm{nM}\left(\mathrm{IC}_{50}\right)$ silver nanoparticle solution was able to block the proliferation and migration of BRECs. The cells showed a clear enhancement in caspase- 3 activity and formation of DNA ladders, evidence of induction of apoptosis. The results showed that silver nanoparticles inhibit cell survival via PI3K/Akt-dependent pathway in BRECs [140].

It is anticipated that nanoparticle-mediated targeted delivery of drugs might significantly reduce the dosage of anticancer drugs with better specificity, enhanced efficacy, and low toxicities. We believe that in the next few years we will see growing number of applications of nanotechnologybased therapeutics and diagnostics in clinics. In addition, individualized medicine is another important area where nanotechnology can play a pivotal role. Due to cancer heterogeneity and development of drug resistance, any particular targeted therapy may not be effective for every population of patients. Moreover, magnetic nanoparticles can be used for hyperthermia cancer treatment. Hyperthermia cancer treatment involves administering magnetic nanoparticles into the body, specifically at cancer tissue sites. Local heating at specific sites is enabled by means of an external magnetic field [141].

3.2. Antibacterial Agent. With the prevalence and increase of microorganisms resistant to multiple antibiotics, silverbased antiseptics have been emphasized in recent years. Silver nanoparticles were biosynthesized using fungus Trichoderma viride [31]. It was observed that the aqueous silver $\left(\mathrm{Ag}^{+}\right)$ ions, when exposed to a filtrate of $T$. viride, were reduced in solution, thereby leading to the formation of extremely stable AgNPs with the size of $5-40 \mathrm{~nm}$. The nanoparticles were also evaluated for their increased antimicrobial activities with various antibiotics against Gram-positive and Gram-negative bacteria. The antibacterial activities of ampicillin, kanamycin, erythromycin, and chloramphenicol were increased in the presence of AgNPs against test strains. The highest enhancing effect was observed for ampicillin against test strains. The result showed that the combination of antibiotics with AgNPs has better antimicrobial effects and provided helpful insight into the development of new antimicrobial agents. Durán and coworkers showed that extracellularly produced silver nanoparticles using Fusarium oxysporum can be incorporated into textile fabrics to prevent or minimize infection with pathogenic bacteria such as Staphylococcus aureus [142].

3.3. Biosensor. Nanoparticles possess interesting electronic and optical properties and can be used in biosensor applications. Spherical selenium nanoparticles formed by the Bacillus subtilis with diameters ranging from 50 to $400 \mathrm{~nm}$ were reported [143]. These spherical monoclinic Se nanoparticles can be transformed into highly anisotropic, one-dimensional (1D) trigonal structure after one day at room temperature since their synthesis. Furthermore, Se nanomaterial crystals with high surface-to-volume ratio, good adhesive ability, and biocompatibility were employed as enhancing and settled materials for building HRP (horseradish peroxidase) biosensor. These sensors exhibited good electrocatalytic activity towards the reduction of $\mathrm{H}_{2} \mathrm{O}_{2}$ due to the good adhesive ability and biocompatibility of Se nanomaterials. These $\mathrm{H}_{2} \mathrm{O}_{2}$ biosensors had high sensitivity and affinity for $\mathrm{H}_{2} \mathrm{O}_{2}$ with a detection limit of $8 \times 10^{-8} \mathrm{M}$. Their results also showed that different crystals of Se nanomaterials had no significant difference in electrochemical application. Thus, the Se nanomaterials-modified electrode will probably be promising for a wide range of applications related to the detection of $\mathrm{H}_{2} \mathrm{O}_{2}$ in food, pharmaceutical, clinical, industrial and environmental analyses. Zheng et al. reported that Au-Ag alloy nanoparticles biosynthesized by yeast cells were applied to fabricate a sensitive electrochemical vanillin sensor [47]. Electrochemical investigations revealed that the vanillin sensor based on Au-Ag alloy nanoparticles-modified glassy carbon electrode was able to enhance the electrochemical response of vanillin for at least five times. Under optimal working conditions, the oxidation peak current of vanillin at the sensor linearly increased with its concentration in the range of $0.2-50 \mu \mathrm{M}$ with a low detection limit of $40 \mathrm{nM}$. This vanillin sensor was successfully applied to the determination of vanillin from vanilla bean and vanilla tea sample, suggesting that it may have practical applications in vanillin monitoring systems. In another study, AuNP-based glucose oxidase $\left(\mathrm{GO}_{\mathrm{x}}\right)$ biosensors were developed based on observations that AuNPs can increase the enzyme activity of $\mathrm{GO}_{\mathrm{x}}$ [144]. The linear response range of the glucose biosensor is $20 \mu \mathrm{M}$ to $0.80 \mathrm{mM}$ glucose with a detection limit of $17 \mu \mathrm{M}(S / N=3)$. This type of biosensor was successfully applied to determine the glucose content in commercial glucose injections.

3.4. Reaction Rate Enhancement Agent. Nanoparticles have been widely used to improve various reactions as reductants and/or catalysts due to their large surface areas and specific characteristics [145]. Magnetic nanoparticles have been used to improve the microbiological reaction rates. In fact, magnetic nanoparticles were utilized not only for their catalytic function but also for their good ability to disperse. Shan et al. made use of the coated microbial cells of 
Pseudomonas delafieldii with magnetic $\mathrm{Fe}_{3} \mathrm{O}_{4}$ nanoparticles to fulfill desulfurization of dibenzothiophene [146]. The high surface energies of nanoparticles resulted in their strong adsorption on the cells. The application of an external magnetic field ensured that the cells were well diffused in the solution even without mixing and enhanced the possibility to collect cells for reuse. The results showed that the desulfurization efficiencies of $P$. delafieldii were not reduced and the cells could be reused several times.

3.5. Magnetic Separation and Detection. Magnetic particles conjugated with biological molecules, which are attractive materials for building assay systems, have been proposed for use as a biological label. Competitive chemiluminescence enzyme immunoassays using antibodies immobilized onto BacMPs were developed for the rapid and sensitive detection of small molecules, such as environmental pollutants, hormone, and toxic detergents [147, 148]. Xenoestrogens, such as alkylphenol ethoxylates, bisphenol A (BPA), and linear alkylbenzene sulonates (LAS), were detectable using monoclonal antibodies immobilized onto BacMPs, based on the competitive reaction of xenoestrogens. The entire procedure was completed in $15 \mathrm{~min}$, while typical plate methods could take more than 2.5 hours. This method provided a wider detection range and lower detection limit than ELISA, in which the same antibodies were used for comparison.

Surface modification of magnetic nanoparticles is an exciting area of research with various potential applications. The BacMP surface can be modified with aminosilane compounds in order to develop magnetic nanoparticle systems for DNA extraction. The use of magnetic particles as a solid-phase adsorbent is well suited for DNA extraction techniques because they can be easily manipulated through simple application of a magnet.

\section{Future Prospects}

There have been tremendous developments in the field of microorganism-produced nanoparticles and their applications over the last decade. However, much work is needed to improve the synthesis efficiency and the control of particle size and morphology. It is known that the synthesis of nanoparticles using microorganisms is a quite slow process (several hours and even a few days) compared to physical and chemical approaches. Reduction of synthesis time will make this biosynthesis route much more attractive. Particle size and monodispersity are two important issues in the evaluation of nanoparticle synthesis. Therefore, effective control of the particle size and monodispersity must be extensively investigated. Several studies have shown that the nanoparticles formed by microorganisms may be decomposed after a certain period of time. Thus, the stability of nanoparticles produced by biological methods deserves further study and should be enhanced [149-151]. Since the control of particle shape in chemical and physical synthesis of nanoparticles is still an ongoing area of research, biological processes with the ability to strictly control particle morphology would therefore offer considerable advantage. By varying parameters like microorganism type, growth stage (phase) of microbial cells, growth medium, synthesis conditions, $\mathrm{pH}$, substrate concentrations, source compound of target nanoparticle, temperature, reaction time, and addition of nontarget ions, it might be possible to obtain sufficient control of particle size and monodispersity. Biosynthesis methods are advantageous also because nanoparticles are sometimes coated with a lipid layer that confers physiological solubility and stability, which is critical for biomedical applications and is the bottleneck of other synthetic methods. Research is currently carried out manipulating cells at the genomic and proteomic levels. With a better understanding of the synthesis mechanism on a cellular and molecular level, including isolation and identification of the compounds responsible for the reduction of nanoparticles, it is expected that short reaction time and high synthesis efficiency can be obtained.

\section{Summary}

Nanomedicine is a burgeoning field of research with tremendous prospects for the improvement of the diagnosis and treatment of human diseases. The biosynthesis of nanoparticles by microbes is thought to be clean, nontoxic, and environmentally acceptable "green chemistry" procedures. The use of microorganisms including bacteria, yeast, fungi, and actinomycetes can be classified into intracellular and extracellular synthesis according to the location where nanoparticles are formed. The rate of intracellular particle formation and therefore the size of the nanoparticles could, to an extent, be manipulated by controlling parameters such as $\mathrm{pH}$, temperature, substrate concentration, and exposure time to substrate. Research is currently carried out manipulating microorganisms at the genomic and proteomic levels. With the recent progress and the ongoing efforts in improving particle synthesis efficiency and exploring their biomedical applications, it is hopeful that the implementation of these approaches on a large scale and their commercial applications in medicine and health care will take place in the coming years.

\section{Abbreviations}

TEM: Transmission Electron Microscope

BacMPs: Bacterial magnetic particles

AgNPs: Silver nanoparticles

AuNPs: Gold nanoparticles

CSE: Cell-soluble extract

GTPase: Guanosine triphosphatase

CdS NPs: CdS nanoparticles

mAbs: Antibodies

MRI: $\quad$ Magnetic resonance imaging

PHB: Polyhydroxybutyrate

BRECs: Bovine retinal endothelial cells

HRP: $\quad$ Horseradish peroxidise

BMs: Baterial magnetosomes

MTB: Magnetotactic bacteria. 


\section{Acknowledgments}

This work was supported in part by the Chinese National Science Foundation (Grant no. 20971050) and Jiangsu Province Oversea Scholarship.

\section{References}

[1] M. C. Daniel and D. Astruc, "Gold nanoparticles: assembly, supramolecular chemistry, quantum-size-related properties, and applications toward biology, catalysis, and nanotechnology," Chemical Reviews, vol. 104, no. 1, pp. 293-346, 2004.

[2] H. Kato, "In vitro assays: tracking nanoparticles inside cells," Nature Nanotechnology, vol. 6, no. 3, pp. 139-140, 2011.

[3] J. Liu, S. Z. Qiao, Q. H. Hu, and G. Q. Lu, "Magnetic nanocomposites with mesoporous structures: synthesis and applications," Small, vol. 7, no. 4, pp. 425-443, 2011.

[4] N. A. Luechinger, R. N. Grass, E. K. Athanassiou, and W. J. Stark, "Bottom-up fabrication of metal/metal nanocomposites from nanoparticles of immiscible metals," Chemistry of Materials, vol. 22, no. 1, pp. 155-160, 2010.

[5] D. K. Tiwari, J. Behari, and P. Sen, "Time and dose-dependent antimicrobial potential of Ag nanoparticles synthesized by top-down approach," Current Science, vol. 95, no. 5, pp. 647655, 2008.

[6] P. Mohanpuria, N. K. Rana, and S. K. Yadav, "Biosynthesis of nanoparticles: technological concepts and future applications," Journal of Nanoparticle Research, vol. 10, no. 3, pp. 507-517, 2008.

[7] R. Bhattacharya and P. Mukherjee, "Biological properties of "naked" metal nanoparticles," Advanced Drug Delivery Reviews, vol. 60, no. 11, pp. 1289-1306, 2008.

[8] K. Simkiss and K. M. Wilbur, Biomineralization, Academic, New York, NY, USA, 1989.

[9] S. Mann, Biomineralization: Principles and Concepts in Bioinorganic Materials Chemistry, Oxford University Press, Oxford, UK, 2001.

[10] X. Zhang, S. Yan, R. D. Tyagi, and R. Y. Surampalli, "Synthesis of nanoparticles by microorganisms and their application in enhancing microbiological reaction rates," Chemosphere, vol. 82, no. 4, pp. 489-494, 2011.

[11] M. A. Hayat, Colloidal Gold: Principles, Methods, and Applications, Academic Press, San Diego, Calif, USA, 1989.

[12] P. Mukherjee, S. Senapati, D. Mandal et al., "Extracellular synthesis of gold nanoparticles by the fungus Fusarium oxysporum," ChemBioChem, vol. 3, no. 5, pp. 461-463, 2002.

[13] A. Ahmad, S. Senapati, M. I. Khan, R. Kumar, and M. Sastry, "Extracellular biosynthesis of monodisperse gold nanoparticles by a novel extremophilic actinomycete, thermomonospora sp," Langmuir, vol. 19, no. 8, pp. 3550-3553, 2003.

[14] P. Mukherjee, A. Ahmad, D. Mandal et al., "Bioreduction of $\mathrm{AuCl}^{-}$ions by the fungus, Verticillium sp. and surface trapping of the gold nanoparticles formed," Angewandte Chemie-International Edition, vol. 40, no. 19, pp. 35853588, 2001.

[15] G. Southam and T. J. Beveridge, "The occurrence of sulfur and phosphorus within bacterially derived crystalline and pseudocrystalline octahedral gold formed in vitro," Geochimica et Cosmochimica Acta, vol. 60, no. 22, pp. 4369-4376, 1996.

[16] A. Ahmad, S. Senapati, M. I. Khan et al., "Intracellular synthesis of gold nanoparticles by a novel alkalotolerant actinomycete, Rhodococcus species," Nanotechnology, vol. 14, no. 7, pp. 824-828, 2003.

[17] M. F. Lengke, M. E. Fleet, and G. Southam, "Morphology of gold nanoparticles synthesized by filamentous cyanobacteria from gold(I)-Thiosulfate and gold(III)-chloride complexes," Langmuir, vol. 22, no. 6, pp. 2780-2787, 2006.

[18] M. F. Lengke, B. Ravel, M. E. Fleet, G. Wanger, R. A. Gordon, and G. Southam, "Mechanisms of gold bioaccumulation by filamentous cyanobacteria from gold(III)-chloride complex," Environmental Science \& Technology, vol. 40, no. 20, pp. 6304-6309, 2006.

[19] B. Nair and T. Pradeep, "Coalescence of nanoclusters and formation of submicron crystallites assisted by lactobacillus strains," Crystal Growth \& Design, vol. 2, no. 4, pp. 293-298, 2002.

[20] G. Singaravelu, J. S. Arockiamary, V. G. Kumar, and K. Govindaraju, "A novel extracellular synthesis of monodisperse gold nanoparticles using marine alga, Sargassum wightii Greville," Colloids and Surfaces B, vol. 57, no. 1, pp. 97-101, 2007.

[21] A. K. Suresh, D. A. Pelletier, W. Wang et al., "Biofabrication of discrete spherical gold nanoparticles using the metalreducing bacterium Shewanella oneidensis," Acta Biomaterialia, vol. 7, no. 5, pp. 2148-2152, 2011.

[22] M. Gericke and A. Pinches, "Biological synthesis of metal nanoparticles," Hydrometallurgy, vol. 83, no. 1-4, pp. 132140, 2006.

[23] L. Du, H. Jiang, X. Liu, and E. Wang, "Biosynthesis of gold nanoparticles assisted by Escherichia coli $D H 5 \alpha$ and its application on direct electrochemistry of hemoglobin," Electrochemistry Communications, vol. 9, no. 5, pp. 11651170, 2007.

[24] M. Agnihotri, S. Joshi, A. R. Kumar, S. Zinjarde, and S. Kulkarni, "Biosynthesis of gold nanoparticles by the tropical marine yeast Yarrowia lipolytica NCIM 3589," Materials Letters, vol. 63, no. 15, pp. 1231-1234, 2009.

[25] M. I. Husseiny, M. A. El-Aziz, Y. Badr, and M. A. Mahmoud, "Biosynthesis of gold nanoparticles using Pseudomonas aeruginosa," Spectrochimica Acta Part A, vol. 67, no. 3-4, pp. 1003-1006, 2007.

[26] S. He, Z. Guo, Y. Zhang, S. Zhang, J. Wang, and N. $\mathrm{Gu}$, "Biosynthesis of gold nanoparticles using the bacteria Rhodopseudomonas capsulata," Materials Letters, vol. 61, no. 18, pp. 3984-3987, 2007.

[27] Y. Konishi, T. Tsukiyama, T. Tachimi, N. Saitoh, T. Nomura, and S. Nagamine, "Microbial deposition of gold nanoparticles by the metal-reducing bacterium Shewanella algae," Electrochimica Acta, vol. 53, no. 1, pp. 186-192, 2007.

[28] A. Panáček, L. Kvítek, R. Prucek et al., "Silver colloid nanoparticles: synthesis, characterization, and their antibacterial activity," The Journal of Physical Chemistry B, vol. 110, no. 33, pp. 16248-16253, 2006.

[29] P. Mukherjee, A. Ahmad, D. Mandal et al., "Fungus-mediated synthesis of silver nanoparticles and their immobilization in the mycelial matrix: a novel biological approach to nanoparticle synthesis," Nano Letters, vol. 1, no. 10, pp. 515519, 2001.

[30] A. Ahmad, P. Mukherjee, S. Senapati et al., "Extracellular biosynthesis of silver nanoparticles using the fungus Fusarium oxysporum," Colloids and Surfaces B, vol. 28, no. 4, pp. 313-318, 2003.

[31] A. M. Fayaz, K. Balaji, M. Girilal, R. Yadav, P. T. Kalaichelvan, and R. Venketesan, "Biogenic synthesis of silver nanoparticles and their synergistic effect with antibiotics: a study against gram-positive and gram-negative bacteria," Nanomedicine: 
Nanotechnology, Biology, and Medicine, vol. 6, no. 1, pp. e103e109, 2010.

[32] T. Klaus, R. Joerger, E. Olsson, and C. -G. Granqvist, "Silverbased crystalline nanoparticles, microbially fabricated," Proceedings of the National Academy of Sciences of the United States of America, vol. 96, no. 24, pp. 13611-13614, 1999.

[33] N. Jain, A. Bhargava, S. Majumdar, J. C. Tarafdar, and J. Panwar, "Extracellular biosynthesis and characterization of silver nanoparticles using Aspergillus flavus NJP08: a mechanism perspective," Nanoscale, vol. 3, no. 2, pp. 635$641,2011$.

[34] N. Vigneshwaran, N. M. Ashtaputre, P. V. Varadarajan, R. P. Nachane, K. M. Paralikar, and R. H. Balasubramanya, "Biological synthesis of silver nanoparticles using the fungus Aspergillus flavus," Materials Letters, vol. 61, no. 6, pp. 14131418, 2007.

[35] K. C. Bhainsa and S. F. D’Souza, "Extracellular biosynthesis of silver nanoparticles using the fungus Aspergillus fumigatus," Colloids and Surfaces B, vol. 47, no. 2, pp. 160-164, 2006.

[36] S. Senapati, D. Mandal, A. Ahmad et al., "Fungus mediated synthesis of silver nanoparticles: a novel biological approach," Indian Journal of Physics A, vol. 78A, no. 1, pp. 101-105, 2004.

[37] K. Kalishwaralal, V. Deepak, S. Ram Kumar Pandian et al., "Biosynthesis of silver and gold nanoparticles using Brevibacterium casei," Colloids and Surfaces B, vol. 77, no. 2, pp. 257-262, 2010.

[38] E. Castro-Longoria, A. R. Vilchis-Nestor, and M. AvalosBorja, "Biosynthesis of silver, gold and bimetallic nanoparticles using the filamentous fungus Neurospora crassa," Colloids and Surfaces B, vol. 83, no. 1, pp. 42-48, 2011.

[39] N. Vigneshwaran, A. A. Kathe, P. V. Varadarajan, R. P. Nachane, and R. H. Balasubramanya, "Biomimetics of silver nanoparticles by white rot fungus, Phaenerochaete chrysosporium," Colloids and Surfaces B, vol. 53, no. 1, pp. 55-59, 2006.

[40] K. Kalimuthu, R. Suresh Babu, D. Venkataraman, M. Bilal, and S. Gurunathan, "Biosynthesis of silver nanocrystals by Bacillus licheniformis," Colloids and Surfaces B, vol. 65, no. 1, pp. 150-153, 2008.

[41] S. Gurunathan, K. Kalishwaralal, R. Vaidyanathan et al., "Biosynthesis, purification and characterization of silver nanoparticles using Escherichia coli," Colloids and Surfaces B, vol. 74, no. 1, pp. 328-335, 2009.

[42] K. Sneha, M. Sathishkumar, J. Mao, I. S. Kwak, and Y. S. Yun, "Corynebacterium glutamicum-mediated crystallization of silver ions through sorption and reduction processes," Chemical Engineering Journal, vol. 162, no. 3, pp. 989-996, 2010.

[43] A. Mohammed Fayaz, K. Balaji, P. T. Kalaichelvan, and R. Venkatesan, "Fungal based synthesis of silver nanoparticlesan effect of temperature on the size of particles," Colloids and Surfaces B, vol. 74, no. 1, pp. 123-126, 2009.

[44] M. M. Juibari, S. Abbasalizadeh, G. S. Jouzani, and M. Noruzi, "Intensified biosynthesis of silver nanoparticles using a native extremophilic Ureibacillus thermosphaericus strain," Materials Letters, vol. 65, no. 6, pp. 1014-1017, 2011.

[45] M. M. G. Babu and P. Gunasekaran, "Production and structural characterization of crystalline silver nanoparticles from Bacillus cereus isolate," Colloids and Surfaces B, vol. 74, no. 1, pp. 191-195, 2009.

[46] S. Senapati, A. Ahmad, M. I. Khan, M. Sastry, and R. Kumar, "Extracellular biosynthesis of bimetallic Au-Ag alloy nanoparticles," Small, vol. 1, no. 5, pp. 517-520, 2005.

[47] D. Zheng, C. Hu, T. Gan, X. Dang, and S. Hu, "Preparation and application of a novel vanillin sensor based on biosynthesis of Au-Ag alloy nanoparticles," Sensors and Actuators B: Chemical, vol. 148, no. 1, pp. 247-252, 2010.

[48] B. D. Sawle, B. Salimath, R. Deshpande, M. D. Bedre, B. K. Prabhakar, and A. Venkataraman, "Biosynthesis and stabilization of Au and Au-Ag alloy nanoparticles by fungus, Fusarium semitectum," Science and Technology of Advanced Materials, vol. 9, no. 3, Article ID 035012, pp. 1-6, 2008.

[49] Y. Konishi, K. Ohno, N. Saitoh et al., "Bioreductive deposition of platinum nanoparticles on the bacterium Shewanella algae," Journal of Biotechnology, vol. 128, no. 3, pp. 648-653, 2007.

[50] A. Sinha and S. K. Khare, "Mercury bioaccumulation and simultaneous nanoparticle synthesis by Enterobacter sp. cells," Bioresource Technology, vol. 102, pp. 4281-4284, 2011.

[51] K. Kashefi and D. R. Lovley, "Reduction of Fe(III), Mn(IV), and toxic metals at $100 \circ \mathrm{C}$ by Pyrobaculum islandicum," Applied and Environmental Microbiology, vol. 66, no. 3, pp. 1050-1056, 2000.

[52] J. R. Lloyd, P. Yong, and L. E. Macaskie, "Enzymatic recovery of elemental palladium by using sulfate-reducing bacteria," Applied and Environmental Microbiology, vol. 64, no. 11, pp. 4607-4609, 1998.

[53] P. Yong, N. A. Rowson, J. P. G. Farr, I. R. Harris, and L. E. Macaskie, "Bioreduction and biocrystallization of palladium by Desulfovibrio desulfuricans NCIMB 8307," Biotechnology and Bioengineering, vol. 80, no. 4, pp. 369-379, 2002.

[54] W. De Windt, P. Aelterman, and W. Verstraete, "Bioreductive deposition of palladium (0) nanoparticles on Shewanella oneidensis with catalytic activity towards reductive dechlorination of polychlorinated biphenyls," Environmental Microbiology, vol. 7, no. 3, pp. 314-325, 2005.

[55] J. H. Lee, J. Han, H. Choi, and H. G. Hur, "Effects of temperature and dissolved oxygen on Se(IV) removal and $\mathrm{Se}(0)$ precipitation by Shewanella sp. HN-41," Chemosphere, vol. 68, no. 10, pp. 1898-1905, 2007.

[56] H. Bao, Z. Lu, X. Cui et al., "Extracellular microbial synthesis of biocompatible CdTe quantum dots," Acta Biomaterialia, vol. 6, no. 9, pp. 3534-3541, 2010.

[57] T. X. Fan, S. K. Chow, and D. Zhang, "Biomorphic mineralization: from biology to materials," Progress in Materials Science, vol. 54, no. 5, pp. 542-659, 2009.

[58] D. A. Bazylinski, A. J. Garratt-Reed, and R. B. Frankel, "Electron microscopic studies of magnetosomes in magnetotactic bacteria," Microscopy Research and Technique, vol. 27, no. 5, pp. 389-401, 1994.

[59] D. A. Bazylinski, R. B. Frankel, B. R. Heywood et al., "Controlled biomineralization of magnetite $\left(\mathrm{Fe}_{3} \mathrm{O}_{4}\right)$ and greigite (Fe3S4) in a magnetotactic bacterium," Applied and Environmental Microbiology, vol. 61, no. 9, pp. 3232-3239, 1995.

[60] A. Arakaki, H. Nakazawa, M. Nemoto, T. Mori, and T. Matsunaga, "Formation of magnetite by bacteria and its application," Journal of the Royal Society Interface, vol. 5, no. 26, pp. 977-999, 2008.

[61] R. Blakemore, "Magnetotactic bacteria," Science, vol. 190, no. 4212, pp. 377-379, 1975.

[62] R. H. Thornhill, J. G. Burgess, and T. Matsunaga, "PCR for direct detection of indigenous uncultured magnetic cocci in sediment and phylogenetic analysis of amplified $16 \mathrm{~S}$ ribosomal DNA," Applied and Environmental Microbiology, vol. 61, no. 2, pp. 495-500, 1995.

[63] S. Spring and K. H. Schleifer, "Diversity of magnetotactic bacteria," Systematic and Applied Microbiology, vol. 18, no. 2, pp. 147-153, 1995. 
[64] T. Perez-Gonzalez, C. Jimenez-Lopez, A. L. Neal et al., "Magnetite biomineralization induced by Shewanella oneidensis," Geochimica et Cosmochimica Acta, vol. 74, no. 3, pp. 967-979, 2010.

[65] K. Zhu, H. Pan, J. Li et al., "Isolation and characterization of a marine magnetotactic spirillum axenic culture QH-2 from an intertidal zone of the China Sea," Research in Microbiology, vol. 161, no. 4, pp. 276-283, 2010.

[66] Y. Amemiya, A. Arakaki, S. S. Staniland, T. Tanaka, and T. Matsunaga, "Controlled formation of magnetite crystal by partial oxidation of ferrous hydroxide in the presence of recombinant magnetotactic bacterial protein Mms6," Biomaterials, vol. 28, no. 35, pp. 5381-5389, 2007.

[67] W. Zhou, W. He, S. Zhong et al., "Biosynthesis and magnetic properties of mesoporous $\mathrm{Fe}_{3} \mathrm{O}_{4}$ composites," Journal of Magnetism and Magnetic Materials, vol. 321, no. 8, pp. 10251028, 2009.

[68] W. Zhou, W. He, X. Zhang et al., "Biosynthesis of iron phosphate nanopowders," Powder Technology, vol. 194, no. 12, pp. 106-108, 2009.

[69] W. Li, L. Yu, P. Zhou, and M. Zhu, "A Magnetospirillum strain WM-1 from a freshwater sediment with intracellular magnetosomes," World Journal of Microbiology and Biotechnology, vol. 23, no. 10, pp. 1489-1492, 2007.

[70] S. Bose, M. F. Hochella, Y. A. Gorby et al., "Bioreduction of hematite nanoparticles by the dissimilatory iron reducing bacterium Shewanella oneidensis MR-1," Geochimica et Cosmochimica Acta, vol. 73, no. 4, pp. 962-976, 2009.

[71] C. T. Lefèvre, F. Abreu, M. L. Schmidt et al., "Moderately thermophilic magnetotactic bacteria from hot springs in Nevada," Applied and Environmental Microbiology, vol. 76, no. 11, pp. 3740-3743, 2010.

[72] A. K. Jha, K. Prasad, and K. Prasad, "A green low-cost biosynthesis of $\mathrm{Sb}_{2} \mathrm{O}_{3}$ nanoparticles," Biochemical Engineering Journal, vol. 43, no. 3, pp. 303-306, 2009.

[73] A. K. Jha and K. Prasad, "Ferroelectric $\mathrm{BaTiO}_{3}$ nanoparticles: biosynthesis and characterization," Colloids and Surfaces B, vol. 75, no. 1, pp. 330-334, 2010.

[74] A. K. Jha, K. Prasad, and A. R. Kulkarni, "Synthesis of $\mathrm{TiO}_{2}$ nanoparticles using microorganisms," Colloids and Surfaces B, vol. 71, no. 2, pp. 226-229, 2009.

[75] V. Bansal, D. Rautaray, A. Bharde et al., "Fungus-mediated biosynthesis of silica and titania particles," Journal of Materials Chemistry, vol. 15, no. 26, pp. 2583-2589, 2005.

[76] V. Bansal, P. Poddar, A. Ahmad, and M. Sastry, "Roomtemperature biosynthesis of ferroelectric barium titanate nanoparticles," Journal of the American Chemical Society, vol. 128, no. 36, pp. 11958-11963, 2006.

[77] V. Bansal, D. Rautaray, A. Ahmad, and M. Sastry, "Biosynthesis of zirconia nanoparticles using the fungus Fusarium oxysporum," Journal of Materials Chemistry, vol. 14, no. 22, pp. 3303-3305, 2004.

[78] C. T. Lefèvre, F. Abreu, U. Lins, and D. A. Bazylinski, "Nonmagnetotactic multicellular prokaryotes from lowsaline, nonmarine aquatic environments and their unusual negative phototactic behavior," Applied and Environmental Microbiology, vol. 76, no. 10, pp. 3220-3227, 2010.

[79] A. Arakaki, M. Shibusawa, M. Hosokawa, and T. Matsunaga, "Preparation of genomic DNA from a single species of uncultured magnetotactic bacterium by multiple-displacement amplification," Applied and Environmental Microbiology, vol. 76, no. 5, pp. 1480-1485, 2010.

[80] H. J. Bai, Z. M. Zhang, Y. Guo, and G. E. Yang, "Biosynthesis of cadmium sulfide nanoparticles by photosynthetic bacteria
Rhodopseudomonas palustris," Colloids and Surfaces B, vol. 70, no. 1, pp. 142-146, 2009.

[81] R. Sanghi and P. Verma, "A facile green extracellular biosynthesis of CdS nanoparticles by immobilized fungus," Chemical Engineering Journal, vol. 155, no. 3, pp. 886-891, 2009.

[82] K. Prasad and A. K. Jha, "Biosynthesis of CdS nanoparticles: an improved green and rapid procedure," Journal of Colloid and Interface Science, vol. 342, no. 1, pp. 68-72, 2010.

[83] R. Y. Sweeney, C. Mao, X. Gao et al., "Bacterial biosynthesis of cadmium sulfide nanocrystals," Chemistry \& Biology, vol. 11, no. 11, pp. 1553-1559, 2004.

[84] M. Kowshik, N. Deshmuke, W. Vogal et al., "Microbial synthesis of semiconductor CdS nanoparticles, their characterization, and their use in the fabrication of an ideal diode," Biotechnology and Bioengineering, vol. 78, no. 5, pp. 583-588, 2002.

[85] C. T. Dameron, R. N. Reese, R. K. Mehra et al., "Biosynthesis of cadmium sulphide quantum semiconductor crystallites," Nature, vol. 338, no. 6216, pp. 596-597, 1989.

[86] H. J. Bai, Z. M. Zhang, and J. Gong, "Biological synthesis of semiconductor zinc sulfide nanoparticles by immobilized Rhodobacter sphaeroides," Biotechnology Letters, vol. 28, no. 14, pp. 1135-1139, 2006.

[87] M. Labrenz, G. K. Druschel, T. Thomsen-Ebert et al., "Formation of sphalerite (ZnS) deposits in natural biofilms of sulfate-reducing bacteria," Science, vol. 290, no. 5497, pp. 1744-1747, 2000.

[88] H. J. Bai and Z. M. Zhang, "Microbial synthesis of semiconductor lead sulfide nanoparticles using immobilized Rhodobacter sphaeroides," Materials Letters, vol. 63, no. 910, pp. 764-766, 2009.

[89] A. Ahmad, P. Mukherjee, D. Mandal et al., "Enzyme mediated extracellular synthesis of CdS nanoparticles by the fungus, Fusarium oxysporum," Journal of the American Chemical Society, vol. 124, no. 41, pp. 12108-12109, 2002.

[90] J. H. P. Watson, D. C. Ellwood, A. K. Soper, and J. Charnock, "Nanosized strongly-magnetic bacterially-produced iron sulfide materials," Journal of Magnetism and Magnetic Materials, vol. 203, no. 1-3, pp. 69-72, 1999.

[91] A. Sanyal, D. Rautaray, V. Bansal, A. Ahmad, and M. Sastry, "Heavy-metal remediation by a fungus as a means of production of lead and cadmium carbonate crystals," Langmuir, vol. 21, no. 16, pp. 7220-7224, 2005.

[92] D. Rautaray, A. Sanyal, S. D. Adyanthaya, A. Ahmad, and M. Sastry, "Biological synthesis of strontium carbonate crystals using the fungus Fusarium oxysporum," Langmuir, vol. 20, no. 16, pp. 6827-6833, 2004.

[93] S. R. K. Pandian, V. Deepak, K. Kalishwaralal, J. Muniyandi, N. Rameshkumar, and S. Gurunathan, "Synthesis of PHB nanoparticles from optimized medium utilizing dairy industrial waste using Brevibacterium casei SRKP2: a green chemistry approach," Colloids and Surfaces B, vol. 74, no. 1, pp. 266-273, 2009.

[94] S. Yan, W. He, C. Sun et al., "The biomimetic synthesis of zinc phosphate nanoparticles," Dyes and Pigments, vol. 80, no. 2, pp. 254-258, 2009.

[95] S. A. Kumar, A. A. Ansary, A. Abroad, and M. I. Khan, "Extracellular biosynthesis of CdSe quantum dots by the fungus, Fusarium oxysporum," Journal of Biomedical Nanotechnology, vol. 3, no. 2, pp. 190-194, 2007.

[96] K. B. Narayanan and N. Sakthivel, "Biological synthesis of metal nanoparticles by microbes," Advances in Colloid and Interface Science, vol. 156, no. 1-2, pp. 1-13, 2010. 
[97] H. Yang, S. Santra, and P. H. Holloway, "Syntheses and applications of Mn-doped II-VI semiconductor nanocrystals," Journal of Nanoscience and Nanotechnology, vol. 5, no. 9, pp. 1364-1375, 2005.

[98] D. P. Cunningham and L. L. Lundie Jr., "Precipitation of cadmium by Clostridium thermoaceticum," Applied and Environmental Microbiology, vol. 59, no. 1, pp. 7-14, 1993.

[99] J. D. Holmes, D. J. Richardson, S. Saed, R. Evans-Gowing, D. A. Russell, and J. R. Sodeau, "Cadmium-specific formation of metal sulfide "Q-particles" by Klebsiella pneumoniae," Microbiology, vol. 143, no. 8, pp. 2521-2530, 1997.

[100] K. Benzerara, J. Miot, G. Morin, G. Ona-Nguema, F. Skouri-Panet, and C. Férard, "Significance, mechanisms and environmental implications of microbial biomineralization," Comptes Rendus Geoscience, vol. 343, no. 2-3, pp. 160-167, 2010.

[101] K. Kalishwaralal, V. Deepak, S. Ramkumarpandian, H. Nellaiah, and G. Sangiliyandi, "Extracellular biosynthesis of silver nanoparticles by the culture supernatant of Bacillus licheniformis," Materials Letters, vol. 62, no. 29, pp. 44114413, 2008.

[102] F. Reith, M. F. Lengke, D. Falconer, D. Craw, and G. Southam, "The geomicrobiology of gold," The ISME Journal, vol. 1, no. 7, pp. 567-584, 2007.

[103] D. H. Nies, "Microbial heavy-metal resistance," Applied Microbiology and Biotechnology, vol. 51, no. 6, pp. 730-750, 1999.

[104] M. Mergeay, S. Monchy, T. Vallaeys et al., "Ralstonia metallidurans, a bacterium specifically adapted to toxic metals: towards a catalogue of metal-responsive genes," FEMS Microbiology Reviews, vol. 27, no. 2-3, pp. 385-410, 2003.

[105] H. Tang, M. Yan, H. Zhang, M. Xia, and D. Yang, "Preparation and characterization of water-soluble CdS nanocrystals by surface modification of ethylene diamine," Materials Letters, vol. 59, no. 8-9, pp. 1024-1027, 2005.

[106] T. Løver, W. Henderson, G. A. Bowmaker, J. M. Seakins, and R. P. Cooney, "Functionalization and capping of a cds nanocluster: a study of ligand exchange by electrospray mass spectrometry," Chemistry of Materials, vol. 9, no. 8, pp. 18781886, 1997.

[107] T. Riddin, M. Gericke, and C. G. Whiteley, "Biological synthesis of platinum nanoparticles: effect of initial metal concentration," Enzyme and Microbial Technology, vol. 46, no. 6, pp. 501-505, 2010.

[108] A. Arakaki, F. Masuda, Y. Amemiya, T. Tanaka, and T. Matsunaga, "Control of the morphology and size of magnetite particles with peptides mimicking the Mms6 protein from magnetotactic bacteria," Journal of Colloid and Interface Science, vol. 343, no. 1, pp. 65-70, 2010.

[109] B. Fadeel and A. E. Garcia-Bennett, "Better safe than sorry: understanding the toxicological properties of inorganic nanoparticles manufactured for biomedical applications," Advanced Drug Delivery Reviews, vol. 62, no. 3, pp. 362-374, 2010.

[110] W. C. W. Chan and S. Nie, "Quantum dot bioconjugates for ultrasensitive nonisotopic detection," Science, vol. 281, no. 5385, pp. 2016-2018, 1998.

[111] F. Tian, A. Prina-Mello, G. Estrada et al., "A novel assay for the quantification of internalized nanoparticles in macrophages," Nanotoxicology, vol. 2, no. 4, pp. 232-242, 2008.

[112] D. Cui, F. Tian, S. R. Coyer et al., "Effects of antisense-mycconjugated single-walled carbon nanotubes on HL-60 cells,"
Journal of Nanoscience and Nanotechnology, vol. 7, no. 4-5, pp. 1639-1646, 2007.

[113] D. Pantarotto, C. D. Partidos, J. Hoebeke et al., "Immunization with peptide-functionalized carbon nanotubes enhances virus-specific neutralizing antibody responses," Chemistry and Biology, vol. 10, no. 10, pp. 961-966, 2003.

[114] R. L. Edelstein, C. R. Tamanaha, P. E. Sheehan et al., "The BARC biosensor applied to the detection of biological warfare agents," Biosensors and Bioelectronics, vol. 14, no. 1011, pp. 805-813, 2000.

[115] A. De la Isla, W. Brostow, B. Bujard et al., "Nanohybrid scratch resistant coatings for teeth and bone viscoelasticity manifested in tribology," Materials Research Innovations, vol. 7, no. 2, pp. 110-114, 2003.

[116] J. Ma, H. Wong, L. B. Kong, and K. W. Peng, "Biomimetic processing of nanocrystallite bioactive apatite coating on titanium," Nanotechnology, vol. 14, no. 6, pp. 619-623, 2003.

[117] M. Shinkai, M. Yanase, M. Suzuki et al., "Intracellular hyperthermia for cancer using magnetite cationic liposomes," Journal of Magnetism and Magnetic Materials, vol. 194, no. 1, pp. 176-184, 1999.

[118] R. Weissleder, G. Elizondo, J. Wittenberg, C. A. Rabito, H. H. Bengele, and L. Josephson, "Ultrasmall superparamagnetic iron oxide: characterization of a new class of contrast agents for MR imaging," Radiology, vol. 175, no. 2, pp. 489-493, 1990.

[119] W. J. Parak, R. Boudreau, M. Le Gros et al., "Cell motility and metastatic potential studies based on quantum dot imaging of phagokinetic tracks," Advanced Materials, vol. 14, no. 12, pp. 882-885, 2002.

[120] D. F. Emerich and C. G. Thanos, "The pinpoint promise of nanoparticle-based drug delivery and molecular diagnosis," Biomolecular Engineering, vol. 23, no. 4, pp. 171-184, 2006.

[121] F. K. Alanazi, A. A. Radwan, and I. A. Alsarra, "Biopharmaceutical applications of nanogold," Saudi Pharmaceutical Journal, vol. 18, no. 4, pp. 179-193, 2010.

[122] E. Rodríguez-Carmona and A. Villaverde, "Nanostructured bacterial materials for innovative medicines," Trends in Microbiology, vol. 18, no. 9, pp. 423-430, 2010.

[123] R. Vaidyanathan, K. Kalishwaralal, S. Gopalram, and S. Gurunathan, "Nanosilver-the burgeoning therapeutic molecule and its green synthesis," Biotechnology Advances, vol. 27, no. 6, pp. 924-937, 2009.

[124] M. Mahmoudi, S. Sant, B. Wang, S. Laurent, and T. Sen, "Superparamagnetic iron oxide nanoparticles (SPIONs): development, surface modification and applications in chemotherapy," Advanced Drug Delivery Reviews, vol. 63, pp. 24-46, 2010.

[125] A. M. G. C. Dias, A. Hussain, A. S. Marcos, and A. C. A. Roque, "A biotechnological perspective on the application of iron oxide magnetic colloids modified with polysaccharides," Biotechnology Advances, vol. 29, no. 1, pp. 142-155, 2011.

[126] Z. Shen, Y. Li, K. Kohama, B. Oneill, and J. Bi, "Improved drug targeting of cancer cells by utilizing actively targetable folic acid-conjugated albumin nanospheres," Pharmacological Research, vol. 63, no. 1, pp. 51-58, 2011.

[127] M. J. Piao, K. A. Kang, I. K. Lee et al., "Silver nanoparticles induce oxidative cell damage in human liver cells through inhibition of reduced glutathione and induction of mitochondria-involved apoptosis," Toxicology Letters, vol. 201, no. 1, pp. 92-100, 2011.

[128] K. V. Chakravarthy, A. C. Bonoiu, W. G. Davis et al., "Gold nanorod delivery of an ssRNA immune activator inhibits pandemic H1N1 influenza viral replication," Proceedings of 
the National Academy of Sciences of the United States of America, vol. 107, no. 22, pp. 10172-10177, 2010.

[129] L. Xiang, J. Wei, S. Jianbo, W. Guili, G. Feng, and L. Ying, "Purified and sterilized magnetosomes from Magnetospirillum gryphiswaldense MSR-1 were not toxic to mouse fibroblasts in vitro," Letters in Applied Microbiology, vol. 45, no. 1, pp. 75-81, 2007.

[130] C. Meng, J. Tian, Y. Li, and S. Zheng, "Influence of native bacterial magnetic particles on mouse immune response," Wei Sheng Wu Xue Bao, vol. 50, no. 6, pp. 817-821, 2010.

[131] J. B. Sun, J. H. Duan, S. L. Dai et al., "In vitro and in vivo antitumor effects of doxorubicin loaded with bacterial magnetosomes (DBMs) on H22 cells: the magnetic bionanoparticles as drug carriers," Cancer Letters, vol. 258, no. 1, pp. 109-117, 2007.

[132] J. B. Sun, Z. L. Wang, J. H. Duan et al., “Targeted distribution of bacterial magnetosomes isolated from magnetospirillum gryphiswaldense MSR-1 in healthy sprague-dawley rats," Journal of Nanoscience and Nanotechnology, vol. 9, no. 3, pp. 1881-1885, 2009.

[133] O. Felfoul, M. Mohammadi, and S. Martel, "Magnetic resonance imaging of $\mathrm{Fe}_{3} \mathrm{O}_{4}$ nanoparticles embedded in living magnetotactic bacteria for potential use as carriers for in vivo applications," in Proceedings of the 29th Annual International Conference of the IEEE Engineering in Medicine and Biology Society (EMBS '07), pp. 1463-1466, 2007.

[134] J. Xie, K. Chen, and X. Chen, "Production, modification and bio-applications of magnetic nanoparticles gestated by magnetotactic bacteria," Nano Research, vol. 2, no. 4, pp. 261278, 2009.

[135] P. Mukherjee, R. Bhattacharya, C. R. Patra et al., Nanogold in Cancer Therapy and Diagnosis, vol. 7, chapter 3, Wiley-VCH, Weinheim, Germany, 2007.

[136] S. Mahdihassan, "Alchemy, Chinese versus Greek, an etymological approach: a rejoinder," American Journal of Chinese Medicine, vol. 16, no. 1-2, pp. 83-86, 1988.

[137] G. J. Higby, "Gold in medicine: a review of its use in the West before 1900," Gold bulletin, vol. 15, no. 4, pp. 130-140, 1982.

[138] C. R. Patra, R. Bhattacharya, D. Mukhopadhyay, and P. Mukherjee, "Fabrication of gold nanoparticles for targeted therapy in pancreatic cancer," Advanced Drug Delivery Reviews, vol. 62, no. 3, pp. 346-361, 2010.

[139] D. A. Giljohann, D. S. Seferos, W. L. Daniel, M. D. Massich, P. C. Patel, and C. A. Mirkin, "Gold nanoparticles for biology and medicine," Angewandte Chemie International Edition, vol. 49, no. 19, pp. 3280-3294, 2010.

[140] K. Kalishwaralal, E. Banumathi, S. R. K. Pandian et al., "Silver nanoparticles inhibit VEGF induced cell proliferation and migration in bovine retinal endothelial cells," Colloids and Surfaces B, vol. 73, no. 1, pp. 51-57, 2009.

[141] B. Chertok, B. A. Moffat, A. E. David et al., "Iron oxide nanoparticles as a drug delivery vehicle for MRI monitored magnetic targeting of brain tumors," Biomaterials, vol. 29, no. 4, pp. 487-496, 2008.

[142] N. Durán, P. D. Marcato, G. I. H. De Souza, O. L. Alves, and E. Esposito, "Antibacterial effect of silver nanoparticles produced by fungal process on textile fabrics and their effluent treatment," Journal of Biomedical Nanotechnology, vol. 3, no. 2, pp. 203-208, 2007.

[143] T. Wang, L. Yang, B. Zhang, and J. Liu, "Extracellular biosynthesis and transformation of selenium nanoparticles and application in $\mathrm{H}_{2} \mathrm{O}_{2}$ biosensor," Colloids and Surfaces $B$, vol. 80, no. 1, pp. 94-102, 2010.
[144] B. Zheng, L. Qian, H. Yuan et al., "Preparation of gold nanoparticles on eggshell membrane and their biosensing application," Talanta, vol. 82, no. 1, pp. 177-183, 2010.

[145] H. Hildebrand, K. Mackenzie, and F.-D. Kopinke, "Novel nano-catalysts for waste water treatment," Global NEST Journal, vol. 10, pp. 47-53, 2008.

[146] G. Shan, J. Xing, H. Zhang, and H. Liu, "Biodesulfurization of dibenzothiophene by microbial cells coated with magnetite nanoparticles," Applied and Environmental Microbiology, vol. 71, no. 8, pp. 4497-4502, 2005.

[147] T. Matsunaga, F. Ueki, K. Obata et al., "Fully automated immunoassay system of endocrine disrupting chemicals using monoclonal antibodies chemically conjugated to bacterial magnetic particles," Analytica Chimica Acta, vol. 475, no. 1-2, pp. 75-83, 2003.

[148] T. Tanaka, H. Takeda, F. Ueki et al., "Rapid and sensitive detection of $17 \beta$-estradiol in environmental water using automated immunoassay system with bacterial magnetic particles," Journal of Biotechnology, vol. 108, no. 2, pp. 153159, 2004.

[149] L. Xiang, W. Bin, J. Huali et al., "Bacterial magnetic particles (BMPs)-PEI as a novel and efficient non-viral gene delivery system," Journal of Gene Medicine, vol. 9, no. 8, pp. 679-690, 2007.

[150] R. Hergt, R. Hiergeist, M. Zeisberger et al., "Magnetic properties of bacterial magnetosomes as potential diagnostic and therapeutic tools," Journal of Magnetism and Magnetic Materials, vol. 293, no. 1, pp. 80-86, 2005.

[151] R. Hergt and S. Dutz, "Magnetic particle hyperthermiabiophysical limitations of a visionary tumour therapy," Journal of Magnetism and Magnetic Materials, vol. 311, no. 1, pp. 187-192, 2007. 

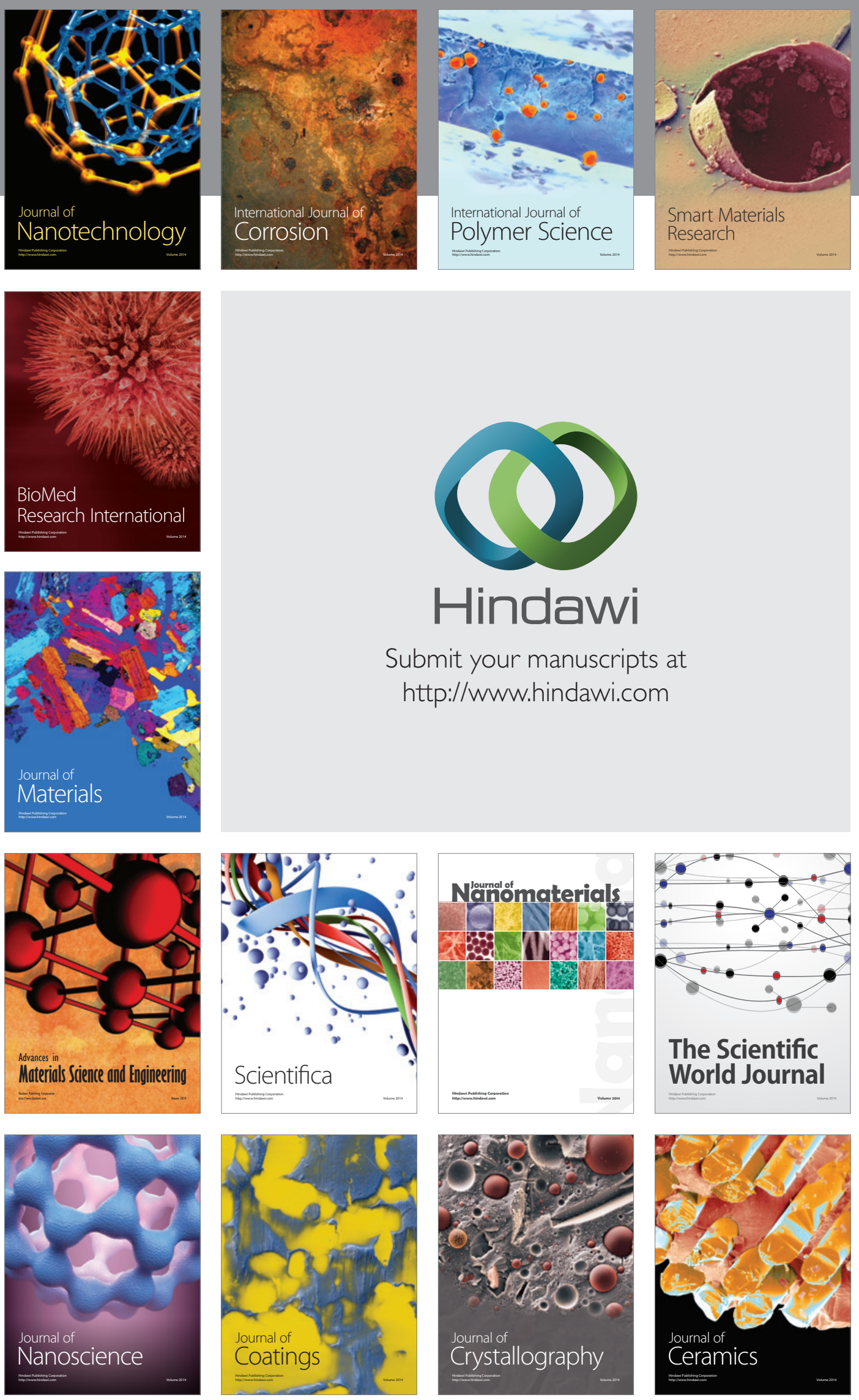

The Scientific World Journal

Submit your manuscripts at

http://www.hindawi.com

\section{World Journal}

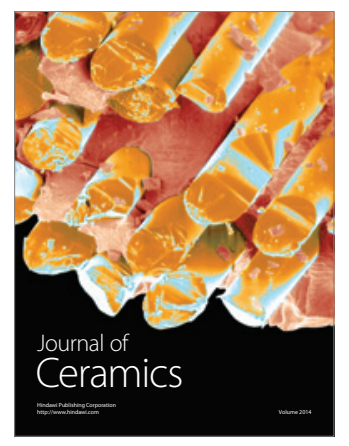

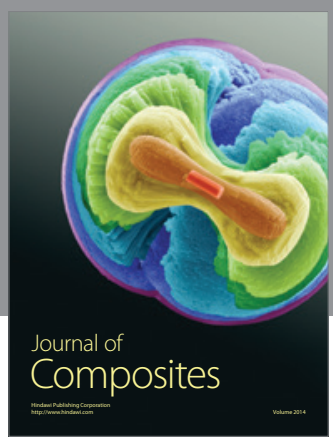
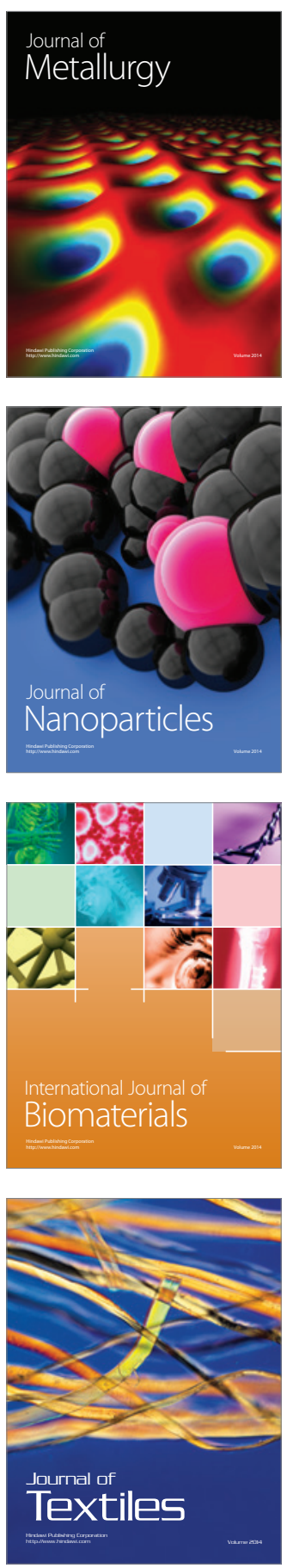